\title{
A study of DNA/BSA interaction and catalytic potential of oxidovanadium(v) complexes with ONO donor ligands $\uparrow$
}

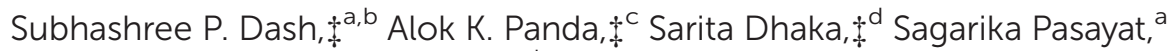 \\ Ashis Biswas, ${ }^{c}$ Mannar R. Maurya, ${ }^{d}$ Paresh Kumar Majhi, ${ }^{a, e}$ Aurélien Crochet $^{f}$ and \\ Rupam Dinda*a
}

\begin{abstract}
The study of DNA/BSA interaction and the catalytic potential of four mononuclear oxidoalkoxido vanadium(V) $\left[\mathrm{V}^{\vee} \mathrm{O}\left(\mathrm{L}^{1-4}\right) \mathrm{OEt}\right](\mathbf{1 - 4})$ and one dinuclear oxidoalkoxido mixed-ligand vanadium $(\mathrm{V})\left[\left\{\mathrm{VO}\left(\mathrm{L}^{2}\right)\right.\right.$ $\left.\mathrm{OEt}\}_{2}(\mathrm{Q})\right]\left\{\mathrm{Q}=4,4^{\prime}\right.$ - bipyridine\}(5) complexes, with tridentate binegative aroylazine ligands are reported [where $\mathrm{H}_{2} \mathrm{~L}^{1}$ = anthranylhydrazone of 2-hydroxy-1-napthaldehyde, $\mathrm{H}_{2} \mathrm{~L}^{2}$ = salicylhydrazone of 2-hydroxy1-napthaldehyde, $\mathrm{H}_{2} \mathrm{~L}^{3}$ = benzoylhydrazone of 2-hydroxy-1-acetonaphthone, $\mathrm{H}_{2} \mathrm{~L}^{4}$ = anthranylhydrazone of 2-hydroxy-1-acetonaphthone]. All the complexes are characterized by elemental analysis as well as various spectroscopic techniques. Single crystal X-ray diffraction crystallography of $\mathbf{2}$ reveals that the metal centre is in distorted square pyramidal geometry with $\mathrm{O}_{4} \mathrm{~N}$ coordination spheres, whereas 5 exhibits a distorted octahedral geometry around the metal center. In addition, all the complexes (1-5) show moderate DNA binding propensity which is investigated using UV-vis absorption titration, circular dichroism, thermal denaturation and fluorescence spectral studies. The experimental results show that the complexes effectively interact with CT-DNA through both minor and major groove binding modes, with binding constants ranging from $10^{4}-10^{5} \mathrm{M}^{-1}$. Among 1-5, complexes 3 and $\mathbf{4}$ show higher binding affinity towards CT-DNA than others and at the same time also exhibit negative $\Delta T_{\mathrm{m}}$ values of about $\sim 1.5$ and $1.0^{\circ} \mathrm{C}$ which resembles the properties shown by cisplatin. All complexes show moderate photoinduced cleavage of pUC19 supercoiled plasmid DNA with complex 3 showing the highest photo induced DNA cleavage activity of $48 \%$. In coherence with the DNA interaction studies, $\mathbf{3}$ and $\mathbf{4}$ also exhibit good binding affinity towards $B S A$ in the range of $10^{10}-10^{11} \mathrm{M}^{-1}$, which is also supported by their ability to quench the tryptophan fluorescence emission spectra of BSA. All the complexes show remarkable photoinduced BSA cleavage activity (>90\%) at a complex concentration of $50 \mu \mathrm{M}$. The catalytic potential of 1-5 is also tested for the oxidative bromination of styrene, salicylaldehyde and oxidation of methyl phenyl sulphide. All the reactions show a high percentage of conversion (>90\%) with a high turnover frequency (TOF). Particularly, in the oxidative bromination of styrene the percentage of conversion and TOF vary from $96-98 \%$ and 8000-19600 $\left(\mathrm{h}^{-1}\right)$ respectively, which signifies the potential of these oxidovanadium(v) complexes to stimulate research for the synthesis of a better catalyst.
\end{abstract}

${ }^{a}$ Department of Chemistry, National Institute of Technology, Rourkela 769008, Odisha, India. E-mail: rupamdinda@nitrkl.ac.in; Fax: +916612462022; Tel: +916612462657

${ }^{b}$ Department of Chemistry, Kuchinda College, Kuchinda, Sambalpur 768222, India ${ }^{c}$ School of Basic Sciences, Indian Institute of Technology Bhubaneswar, Bhubaneswar 751 013, Odisha, India

${ }^{d}$ Department of Chemistry, Indian Institute of Technology Roorkee, Roorkee 247667, India ${ }^{e}$ Institute for Chemical Research, Kyoto University, Gokasho Uji, Kyoto 611-0011, Japan ${ }^{f}$ Fribourg Center for Nanomaterials, Department of Chemistry,

University of Fribourg, CH-1700 Fribourg, Switzerland

$\uparrow$ Electronic supplementary information (ESI) available: Tables S1-S5 and Fig. S1-S14. CCDC 1482859 (2) and 1482860 (5). For ESI and crystallographic data in CIF or other electronic format see DOI: 10.1039/c6dt03228a

$\ddagger$ These authors contributed equally to this work.

\section{Introduction}

The chemistry of vanadium is currently a subject of extensive research because of its increasingly recognized biochemical importance. ${ }^{1}$ Since the discovery of high concentrations of vanadium in the blood of ascidians by Henze in $1911,{ }^{2}$ it has been identified as an essential element for some important vanadium-containing enzymes, nitrogenase ${ }^{3}$ haloperoxidase ${ }^{4}$ nitrate reductases ${ }^{5}$ and also for Amavadin, ${ }^{6}$ a compound isolated from the mushroom Amanita muscaria, that has been shown to contain an octacoordinated $\mathrm{V}^{4+}$ ion. ${ }^{7}$ A vanadium protein has also been proposed to catalyze the oxidation of 
NADH. ${ }^{8}$ Moreover, several vanadium compounds have been shown to be active as insulin mimetics in vitro and in vivo, ${ }^{9}$ including clinical tests, demonstrating the usability of simple inorganic (vanadyl sulfate, vanadate) ${ }^{10}$ and coordination compounds $\left[\mathrm{VO}(\text { maltolato })_{2}\right]^{11}$ for the treatment of diabetes mellitus in humans. The distinct preference of this metal center for O- and/or N-coordination environments, as delineated by Extended X-Ray Absorption Fine Structure (EXAFS), ${ }^{12}$ and crystallographic studies ${ }^{13}$ on haloperoxidase, has prompted the synthesis of numerous model vanadium compounds containing $\mathrm{O}-$ and $\mathrm{N}$-donor ligands, whose solid state structure, and spectroscopic, magnetic and redox properties have been widely investigated.

Metal based drug designing is an area of contemporary research interest due to the wide spread use of existing anticancer drugs such as cisplatin and its derivatives and also due to the limitations and disadvantages associated with them. Due to the central role of DNA in replication and transcription, it is the main target of antitumorals. Hence the origin of anticancer activity of metal complexes has been attributed to the ability of the metal ion to cleave DNA. ${ }^{14}$ The interaction of metal complexes with DNA is also of great interest since it is useful in designing new and promising drugs,${ }^{15}$ probes for nucleic acids, ${ }^{16}$ DNA-dependent electron transfer reactions, DNA footprinting, sequence-specific cleaving agents and antitumor drugs. ${ }^{17}$ The interactions may be covalent or noncovalent, which solely depend on the nature of the metal and the ligand. ${ }^{17 d, 18}$ Non-covalent interactions between transitionmetal complexes and DNA can occur by intercalation between base-pairs, groove binding (minor/major), or external electrostatic binding. Hence it is very essential to study the interaction of metal complexes with DNA that could probably have different DNA-binding modes as well as show different biological profiles which would be very useful for the design of new chemotherapy drugs and their application. ${ }^{19}$ In a similar way, proteins are the main cellular target of anticancer drugs. Hence it is essential to study protein-drug interactions that greatly affect the absorption, distribution, activity, and toxicity of drugs. ${ }^{20}$ Among transition metal complexes, vanadium is very specific due its low toxicity, wide range of coordination numbers and geometries, available redox states, and thermodynamic and kinetic characteristics. It has also been reported that reactive oxygen species are generated during the reaction of vanadyl ions in vivo causing the increase of apoptotic cells, ${ }^{21}$ which may be a reason for vanadium complexes to be used as antitumor drugs. ${ }^{22}$

Moreover, the discovery of vanadate(v)-dependent haloperoxidases aroused interest in the catalytic activity of vanadium(v) complexes, where the vanadium(v) ions act as the active center for the halogenation of organic species in the presence of hydrogen peroxide and a halide anion..$^{23}$ The ability of this metal to possess different oxidation states which are easily interconvertible, high affinity for oxygen and the Lewis acidic nature extends its application in redox and Lewis acid catalyzed reactions. ${ }^{24}$ Vanadium complexes are well known to catalyze the oxidation of saturated hydrocarbons, ${ }^{25}$ olefins, ${ }^{26}$ aromatic compounds, ${ }^{27}$ benzylic alcohols, diols, phenols, ${ }^{28}$ sulfides, and halides. ${ }^{29}$ Traditional methods using hazardous stoichiometric reactions of permanganate, chromate, or hypochlorite for oxidation are replaced by the use of peroxide and dioxygen, due to growing environmental issues. However these oxidants are needed to be activated owing to their weak oxidizing nature, which is resolved to a certain extent by the use of metal complexes including vanadium ${ }^{30}$ as a catalyst. Hence the development of new generation catalysts with a high turnover number (TON), selectivity and sustainability is a frontline area of current research.

Over the past few years, we have been studying the chemistry of oxido-metal complexes including those of vanadium, in $\mathrm{O}, \mathrm{N}$-donor environments ${ }^{31,32}$ with the electrogeneration of mixed-valence divanadium(Iv,v) complexes, ${ }^{31 a, 32 a}$ and the antiproliferative, DNA binding, photo-induced DNA cleavage and insulin mimetic activity of variable valence oxido and nonoxido vanadium complexes. ${ }^{32 d, e}$

Herein, we now report the chemistry of five mono- and dinuclear oxidoethoxido vanadium(v) complexes (1-5) in relation to biological and catalytic activities. All the complexes are characterized by spectroscopy and the structural features of 2 and 5 have been solved by X-ray crystallography. All the complexes show interesting DNA/BSA binding and photoinduced DNA cleavage activities and are also found to show good catalytic potential for the oxidative bromination of styrene, salicylaldehyde and oxidation of methyl phenyl sulphide. It is significant to mention that there are very few reports in the literature where the catalytic efficiency of vanadium complexes in relation to their DNA/BSA interaction has been reported. ${ }^{33}$

\section{Experimental section}

\section{Materials and methods}

All chemicals were purchased from commercial sources and used without further purification. Reagent grade solvents were dried and distilled prior to use. The Schiff-base ligands namely anthranylhydrazone of 2-hydroxy-1-napthaldehyde $\left(\mathrm{H}_{2} \mathrm{~L}^{1}\right)$, salicylhydrazone of 2-hydroxy-1-napthaldehyde $\left(\mathrm{H}_{2} \mathrm{~L}^{2}\right)$, benzoylhydrazone of 2-hydroxy-1-acetonaphthone $\left(\mathrm{H}_{2} \mathrm{~L}^{3}\right)$ and anthranylhydrazone of 2-hydroxy-1-acetonaphthone $\left(\mathrm{H}_{2} \mathrm{~L}^{4}\right)$ were prepared by a previously reported procedure. ${ }^{34}$ Elemental analyses were performed on a Vario EL cube CHNS Elemental analyzer. IR spectra were recorded on a Perkin-Elmer Spectrum RXI spectrophotometer. ${ }^{1} \mathrm{H}$ and ${ }^{13} \mathrm{C}$ NMR spectra were recorded on a Bruker Ultrashield $400 \mathrm{MHz}$ spectrometer using $\mathrm{SiMe}_{4}$ as an internal standard. Electronic spectra were recorded on a Lambda 25 PerkinElmer spectrophotometer. The supercoiled (SC) pUC19 DNA was purified from E. coli cells with the aid of a GeneJET Plasmid Isolation Kit (Thermo Scientific, USA). Calf thymus (CT) DNA was purchased from SRL (India) (biochemistry grade). Agarose (molecular biology grade) and bovine serum albumin (BSA) were purchased from Sigma Aldrich (USA). A Shimadzu 2010 plus gas-chromatograph fitted with an Rtx-1 capillary column $(30 \mathrm{~m} \times 0.25 \mathrm{~mm} \times$ 
$0.25 \mu \mathrm{m}$ ) and a flame ionization detector (FID) were used to analyze the reaction products and their quantifications were made on the basis of the relative peak area of the respective product. The identity of the products was confirmed using a GC-MS model Perkin-Elmer, Clarus 500 and comparing the fragments of each product with the library available. The percent conversion of the substrate and selectivity of the products was calculated from GC data using the formulae:

$\%$ Conversion of substrate $=$

$$
100-\frac{\text { Peak area of a substrate }}{\text { Total area of substrate }+ \text { products }} \times 100
$$

$\%$ Selectivity of a product $=\frac{\text { Peak area of a product }}{\text { Total area of products }} \times 100$

Caution! Although we have not encountered problems, it is worthy of note that perchlorate salts are potentially explosive and should be handled only in small quantities with appropriate precautions.

\section{Synthesis of complexes $\left[\mathrm{VO}\left(\mathrm{L}^{1-4}\right) \mathrm{OEt}\right](1-4)$}

Complexes 1-4 were prepared by a reported method. ${ }^{35}$ Ammonium metavanadate $\left[\mathrm{NH}_{4} \mathrm{VO}_{3}\right](1 \mathrm{mmol})$ was added to a hot solution of an appropriate ligand, $\mathrm{H}_{2} \mathrm{~L}^{1-4}(1 \mathrm{mmol})$ in EtOH $(20 \mathrm{~mL})$; the color changed instantly to brown. After $3 \mathrm{~h}$ of refluxing, the reaction mixture was filtered off and kept for crystallization. After 3 to 4 days, crystals of diffraction quality were obtained which were used for X-ray structure determination using a single crystal X-ray diffractometer.

[VO(L $\left.\mathbf{L}^{\mathbf{1}}\right) \mathbf{O E t}$ ] (1). Yield: $0.25 \mathrm{~g}(0.61 \mathrm{mmol}), 61 \%$. Anal. calcd for $\mathrm{C}_{20} \mathrm{H}_{18} \mathrm{~N}_{3} \mathrm{O}_{4} \mathrm{~V}$ (415.31): C, 57.84; H, 4.37; N, 10.12. Found: $\mathrm{C}, 57.83 ; \mathrm{H}, 4.39 ; \mathrm{N}, 10.08$. IR ( $\mathrm{KBr}$ pellet, $\mathrm{cm}^{-1}$ ): 3461 $\nu\left(\mathrm{NH}_{2}\right)_{\mathrm{as}}, 3322 \nu\left(\mathrm{NH}_{2}\right)_{\mathrm{s}}, 1595 \nu(\mathrm{C}=\mathrm{N}), 1255(\mathrm{C}-\mathrm{O})_{\text {enolic }}, 991$ $(\mathrm{V}=\mathrm{O})$. UV-vis $\left(\mathrm{CHCl}_{3}\right)\left[\lambda_{\max }, \mathrm{nm}\left(\varepsilon, \mathrm{M}^{-1} \mathrm{~cm}^{-1}\right)\right]: 434$ (15 257), 336 (19 651), 286 (26 852), 248 (30 614). ${ }^{1} \mathrm{H}$ NMR (400 MHz, DMSO- $\left.d_{6}\right): \delta 9.80(\mathrm{~s}, 1 \mathrm{H}, \mathrm{HC}=\mathrm{N}), 8.49-6.57(\mathrm{~m}, 10 \mathrm{H}$, aromatic), 5.73-5.54 (m, 2H, $\mathrm{CH}_{2}$ (OEt)), $4.33\left(\mathrm{~s}, 2 \mathrm{H}, \mathrm{NH}_{2}\right)$, 1.60-1.57 (t, 3H, $\mathrm{CH}_{3}$ (OEt)). ${ }^{13} \mathrm{C}$ NMR (100 MHz, DMSO- $\left.d_{6}\right)$ : $\delta 171.0,164.2$, 149.6, 148.1, 135.0, 132.8, 132.2, 130.5, 129.2, $128.5,128.3,124.2,121.9,119.7,116.3,115.0,111.6,111.0$, 81.7, 18.7 .

[VO(L $\left.\mathbf{L}^{2}\right) \mathrm{OEt}$ (2). Yield: $0.27 \mathrm{~g}(0.65 \mathrm{mmol}), 65 \%$. Anal. calcd for $\mathrm{C}_{20} \mathrm{H}_{17} \mathrm{~N}_{2} \mathrm{O}_{5} \mathrm{~V}$ (416.30): C, 57.70; H, 4.12; N, 6.73. Found: C, 57.72; H, 4.08; N, 6.77. IR ( $\mathrm{KBr}$ pellet, $\left.\mathrm{cm}^{-1}\right): 3442(\mathrm{O}-\mathrm{H})$, $1597 \nu(\mathrm{C}=\mathrm{N}), 1254(\mathrm{C}-\mathrm{O})_{\text {enolic }}, 996(\mathrm{~V}=\mathrm{O})$. UV-vis $\left(\mathrm{CHCl}_{3}\right)$ $\left[\lambda_{\max }, \mathrm{nm}\left(\varepsilon, \mathrm{M}^{-1} \mathrm{~cm}^{-1}\right)\right]: 425$ (12 649), 339 (20 637), 273 (27 392), 245 (27 822). ${ }^{1} \mathrm{H}$ NMR (400 MHz, DMSO- $d_{6}$ ): $\delta 11.61$ (s, 1H, OH), $9.94(\mathrm{~s}, 1 \mathrm{H}, \mathrm{HC}=\mathrm{N}), 8.56-6.97(\mathrm{~m}, 10 \mathrm{H}$, aromatic), 5.86-5.66 (m, 2H, $\mathrm{CH}_{2}$ (OEt)), 1.63-1.59 (t, 3H, $\mathrm{CH}_{3}$ (OEt)). ${ }^{13} \mathrm{C}$ NMR (100 MHz, DMSO- $\left.d_{6}\right): \delta 170.2,164.3,159.0,149.0,135.3$, $133.3,132.9,129.3,129.0,128.6,128.3,124.1,121.8,119.4$, 119.0, 116.9, 114.6, 111.4, 83.1, 18.2.

[VO( $\left.\mathbf{L}^{3}\right)$ OEt] (3). Yield: $0.27 \mathrm{~g}$ (0.66 mmol), 66\%. Anal. calcd for $\mathrm{C}_{21} \mathrm{H}_{19} \mathrm{~N}_{2} \mathrm{O}_{4} \mathrm{~V}$ (414.32): C, 60.88; H, 4.62; N, 6.76. Found: C, 60.86; H, 4.58; N, 6.77. IR ( $\mathrm{KBr}$ pellet, $\left.\mathrm{cm}^{-1}\right): 1595 \nu(\mathrm{C}=\mathrm{N})$,
$1239(\mathrm{C}-\mathrm{O})_{\text {enolic }}, 999(\mathrm{~V}=\mathrm{O})$. UV-vis $\left(\mathrm{CHCl}_{3}\right)\left[\lambda_{\max }, \mathrm{nm}\right.$ $\left.\left(\varepsilon, \mathrm{M}^{-1} \mathrm{~cm}^{-1}\right)\right]: 430$ (7003), 343 (14 511), 286 (21 713), 234 (25 207). ${ }^{1} \mathrm{H}$ NMR (400 MHz, DMSO- $\left.d_{6}\right): \delta 8.09-7.20(\mathrm{~m}, 11 \mathrm{H}$, aromatic), 5.54-5.41 (m, 2H, $\mathrm{CH}_{2}$ (OEt)), $2.92\left(\mathrm{~s}, 3 \mathrm{H}, \mathrm{CH}_{3}\right)$, 1.53-1.49 (t, $\left.3 \mathrm{H}, \mathrm{CH}_{3}(\mathrm{OEt})\right) .{ }^{13} \mathrm{C}$ NMR (100 MHz, DMSO- $\left.d_{6}\right)$ : $\delta$ 170.8, 166.1, 159.7, 133.8, 131.9, 131.7, 131.6, 129.5, 129.2, 128.8, 128.4, 127.4, 126.1, 124.2, 119.4, 118.1, 80.2, 23.6, 18.7.

[VO(L $\left.{ }^{4}\right)$ OEt] (4). Yield: $0.28 \mathrm{~g}(0.64 \mathrm{mmol}), 64 \%$. Anal. calcd for $\mathrm{C}_{21} \mathrm{H}_{20} \mathrm{~N}_{3} \mathrm{O}_{4} \mathrm{~V}$ (429.34): C, 58.75; H, 4.70; N, 9.79. Found: C, 58.74; H, 4.73; N, 9.78. IR ( $\mathrm{KBr}$ pellet, $\left.\mathrm{cm}^{-1}\right)$ : $1567 \nu(\mathrm{C}=\mathrm{N})$, $1238(\mathrm{C}-\mathrm{O})_{\text {enolic, }} 996(\mathrm{~V}=\mathrm{O})$. UV-vis $\left(\mathrm{CHCl}_{3}\right)\left[\lambda_{\max }, \mathrm{nm}\right.$ $\left.\left(\varepsilon, \mathrm{M}^{-1} \mathrm{~cm}^{-1}\right)\right]$ : 419 (14 445), 307 (18 634), 277 (24 006), 253 (30 231). ${ }^{1} \mathrm{H}$ NMR (400 MHz, DMSO- $\left.d_{6}\right): \delta 8.09-6.60(\mathrm{~m}, 10 \mathrm{H}$, aromatic), 5.56-5.41 (m, 2H, $\left.\mathrm{CH}_{2}(\mathrm{OEt})\right), 4.51$ (s, 2H, $\mathrm{NH}_{2}$ ), $2.86\left(\mathrm{~s}, 3 \mathrm{H}, \mathrm{CH}_{3}\right), 1.55-1.52\left(\mathrm{t}, 3 \mathrm{H}, \mathrm{CH}_{3}(\mathrm{OEt})\right) .{ }^{13} \mathrm{C} \mathrm{NMR}$ (100 MHz, DMSO- $\left.d_{6}\right): \delta 171.9,165.9,158.2,149.7,133.6,132.3$, $131.9,130.5,129.1,127.3,126.0,124.1,119.2,118.0,116.2$, $115.2,111.2,80.0,23.6,18.5$.

\section{Synthesis of a mixed-ligand complex $\left[\left\{\mathrm{VO}\left(\mathrm{L}^{2}\right) \mathrm{OEt}\right\}_{2}\right.$ ( $\mu-4, \mathbf{4}^{\prime}$-bipy)] (5)}

To the refluxing solution of the ligand, $\mathrm{H}_{2} \mathrm{~L}^{2}(1 \mathrm{mmol})$ in $20 \mathrm{~mL}$ ethanol, 4,4'-bipyridine (0.5 mmol) was added. After $10 \mathrm{~min}$, ammonium metavanadate $\left[\mathrm{NH}_{4} \mathrm{VO}_{3}\right](1 \mathrm{mmol})$ was added to the reaction mixture. The color changed to brown. After $3 \mathrm{~h}$, the solution was filtered off, and kept for crystallization. Slow evaporation of the filtrate over 5-6 days, produced crystals of diffraction quality, which were used for X-ray structure determination using a single crystal X-ray diffractometer.

[\{VO( $\left.\left.\mathbf{L}^{2}\right) \mathbf{O E t}\right\}_{2}\left(\boldsymbol{\mu}-\mathbf{4}, \mathbf{4}^{\prime}\right.$-bipy $\left.)\right]$ (5). Yield: $0.20 \mathrm{~g}(0.21 \mathrm{mmol})$, $41 \%$. Anal. calcd for $\mathrm{C}_{50} \mathrm{H}_{42} \mathrm{~N}_{6} \mathrm{O}_{10} \mathrm{~V}_{2}$ (988.77): C, 60.73; H, 4.28; $\mathrm{N}$, 8.49. Found: C, 60.70; H, 4.24; N, 8.52. IR ( $\mathrm{KBr}$ pellet, $\left.\mathrm{cm}^{-1}\right): 1599 \nu(\mathrm{C}=\mathrm{N}), 1252 \nu\left(\mathrm{C}-\mathrm{O}_{\text {enolic }}\right), 1049 \nu(\mathrm{N}-\mathrm{N}), 959$ $\nu(\mathrm{V}=\mathrm{O})$. UV-vis $\left(\mathrm{CHCl}_{3}\right)\left[\lambda_{\max }, \mathrm{nm}\left(\varepsilon, \mathrm{M}^{-1} \mathrm{~cm}^{-1}\right)\right]: 435$ (7831), 331 (14651), 281 (12 719), 259 (18 603). ${ }^{1} \mathrm{H}$ NMR (400 MHz, DMSO- $\left.d_{6}\right): \delta 11.59(\mathrm{~s}, 1 \mathrm{H}, \mathrm{OH}), 9.89(\mathrm{~s}, 1 \mathrm{H}, \mathrm{CH}), 8.70-6.94(\mathrm{~m}$, $14 \mathrm{H}$, aromatic), 5.83-5.71 (m, 2H, $\left.\mathrm{CH}_{2}(\mathrm{OEt})\right), 1.63-1.59(\mathrm{t}, 3 \mathrm{H}$, $\mathrm{CH}_{3}$ (OEt)). ${ }^{13} \mathrm{C}$ NMR (100 MHz, DMSO- $\left.d_{6}\right): \delta$ 170.1, 164.3, $159.0,150.5,149.2,145.1,135.5,133.5,132.9,129.4,129.1$, $128.6,128.4,124.3,122.0,121.7,119.6,119.2$, 117.1, 114.6, 111.4, 83.1, 18.6.

\section{X-ray crystallography}

Crystallographic data and details of refinement are given in Table S1. $\uparrow$ More details are discussed in the ESI. $\uparrow^{36,37}$

\section{DNA binding experiments}

Absorption spectral studies. Binding of the oxidoethoxido vanadium(v) complexes to calf thymus DNA (CT-DNA) was studied in $10 \mathrm{mM}$ Tris-HCl buffer $(\mathrm{pH}$ 8.0) containing $1 \%$ DMF as described previously ${ }^{32 e}$ (more details are discussed in the $\mathrm{ESI} \dagger$ ).

Thermal denaturation studies. Thermal denaturation studies of CT-DNA $(150 \mu \mathrm{M})$ in the absence and presence of complexes $(50 \mu \mathrm{M})$ was carried out by monitoring the absorbance at $260 \mathrm{~nm}$ in the temperature range of $30-90{ }^{\circ} \mathrm{C}$ with a 
ramp rate of $0.5{ }^{\circ} \mathrm{C} \mathrm{min}^{-1}$ in $10 \mathrm{mM}$ Tris-HCl buffer $(\mathrm{pH} 8.0)$ containing $1 \%$ DMF. The denaturation experiments were carried out using a Chirascan CD spectropolarimeter (Applied Photophysics, UK) in absorbance mode equipped with a quantum temperature controller. A significant hyperchromicity was observed at $260 \mathrm{~nm}$ upon the melting of the double stranded DNA to single stranded DNA. The melting temperature $\left(T_{\mathrm{m}}\right)$ was determined from the derivative plot $\left(\mathrm{d} A_{260} / \mathrm{d} T\right.$ vs. $T$ ) of the melting profile. ${ }^{32 e}$

Circular dichroism studies. Circular Dichroism (CD) spectroscopy was studied using a Chirascan CD spectropolarimeter (Applied Photophysics, UK) as described previously. ${ }^{38}$ Briefly, the spectra of $150 \mu \mathrm{M}$ of CT-DNA in the absence and presence of complexes $(25 \mu \mathrm{M})$ were obtained in the wavelength range of 240-300 nm in $10 \mathrm{mM}$ Tris-HCl buffer ( $\mathrm{pH}$ 8.0) containing 1\% DMF using a quartz cell.

Competitive DNA binding fluorescence measurements. The competitive binding experiments were carried out as described previously ${ }^{39}$ (more details are discussed in the ESI $\dagger$ ).

\section{DNA cleavage experiments}

For DNA cleavage experiments, $300 \mathrm{ng}$ supercoiled (SC) pUC19 DNA was used and all experiments were carried out in $50 \mathrm{mM}$ Tris-HCl buffer ( $\mathrm{pH}$ 8.0) containing 1\% DMF and $10 \mathrm{mM}$ phosphate buffer ( $\mathrm{pH} 7.8$ ) containing $1 \% \mathrm{DMF}^{40}$

Chemical-induced DNA cleavage. Chemical nuclease studies were performed in the dark using hydrogen peroxide $(0.5 \mathrm{mM})$ as the oxidising agent in the absence and presence of complexes $(1-500 \mu \mathrm{M})$. The solutions were first incubated at $37{ }^{\circ} \mathrm{C}$ for $3 \mathrm{~h}$ and thereafter the DNA cleaved products were analysed by agarose gel electrophoresis.

Photo-induced DNA cleavage. The effect of oxidoalkoxido vanadium(v) complexes $(1-500 \mu \mathrm{M})$ on the photo-induced cleavage of supercoiled (SC) pUC19 DNA (300 ng) was studied by agarose gel electrophoresis in both $50 \mathrm{mM}$ Tris-HCl buffer ( $\mathrm{pH}$ 8.0) containing 1\% DMF and $10 \mathrm{mM}$ phosphate buffer (pH 7.8) containing $1 \%$ DMF as described previously. ${ }^{40}$ The photo cleavage reactions were carried out under illuminated conditions using a UVA source at $350 \mathrm{~nm}$ (Luzchem Photoreactor Model LZC-1, Ontario, Canada) fitted with 14 UVA tubes, for $3 \mathrm{~h}$ at room temperature (more details are discussed in the ESI $\dagger$ ). ${ }^{41}$

\section{Protein binding and cleavage experiments}

Bovine serum albumin (BSA) interaction studies. The protein binding study was performed by tryptophan fluorescence quenching experiments using BSA $(2 \mu \mathrm{M})$ as a substrate in $10 \mathrm{mM}$ Tris-HCl buffer ( $\mathrm{pH}$ 8.0) containing 1\% DMF using a Fluoromax 4P spectrofluorimeter (Horiba Jobin Mayer, USA). The quenching of the emission intensity of the tryptophan residues of BSA at $344 \mathrm{~nm}$ (excitation at $295 \mathrm{~nm}$ ) was monitored with increasing complex concentration $[0-4 \mu \mathrm{M}$ in $10 \mathrm{mM}$ Tris-HCl buffer ( $\mathrm{pH}$ 8.0) containing $1 \% \mathrm{DMF}]^{40}$ (more details are discussed in the ESI $\dagger$ ).

Photo-induced BSA cleavage studies. A freshly prepared solution of BSA in $10 \mathrm{mM}$ Tris-HCl buffer ( $\mathrm{pH}$ 8.0) containing 1\%
DMF was used for photochemical protein cleavage studies. ${ }^{40}$ BSA $(5 \mu \mathrm{M})$ solution in the absence and presence of complexes $[1-300 \mu \mathrm{M}$ in $10 \mathrm{mM}$ Tris-HCl buffer $(\mathrm{pH}$ 8.0) containing $1 \% \mathrm{DMF}$ ] was photo-irradiated using a UVA source at $350 \mathrm{~nm}$ (Luzchem Photoreactor Model LZC-1, Ontario, Canada) fitted with 14 UVA tubes for $90 \mathrm{~min}$. The irradiated samples $(20 \mu \mathrm{L})$ were dissolved in loading buffer $(20 \mu \mathrm{L})$ containing SDS $(7 \% \mathrm{w} / \mathrm{v})$, glycerol $(4 \% \mathrm{w} / \mathrm{v})$, Tris-HCl buffer (50 mM, pH 6.8), mercaptoethanol ( $2 \% \mathrm{v} / \mathrm{v})$ and bromophenol blue $(0.01 \% \mathrm{w} / \mathrm{v})$. The samples were then denatured by heat at $100{ }^{\circ} \mathrm{C}$ for $5 \mathrm{~min}$ and loaded onto a 12\% SDS PAGE separating gel. The gels were photographed by using the UVP (Gel Doc $\mathrm{It}^{2}$ ) Gel Documentation System. Molecular weight markers were used in each gel to calibrate the molecular weight of BSA. $^{40}$

\section{Catalytic reactions}

Oxidative bromination of styrene. Complexes 1-5 were used as catalyst precursors to carry out the oxidative bromination of styrene. In a typical reaction, styrene $(1.04 \mathrm{~g}, 10 \mathrm{mmol})$ was added to an aqueous solution ( $5 \mathrm{~mL})$ of $\mathrm{KBr}(3.57 \mathrm{~g}, 30 \mathrm{mmol})$, followed by the addition of $\mathrm{CH}_{3} \mathrm{CN}(20 \mathrm{~mL})$ and $30 \%$ aqueous $\mathrm{H}_{2} \mathrm{O}_{2}(3.39 \mathrm{~g}, 30 \mathrm{mmol})$ in a $100 \mathrm{~mL}$ reaction flask. The catalyst $(0.0005 \mathrm{~g})$ and $70 \% \mathrm{HClO}_{4}(0.715 \mathrm{~g}, 5 \mathrm{mmol})$ were added, and the reaction mixture was stirred at room temperature. Three additional $5 \mathrm{mmol}$ portions of $70 \% \mathrm{HClO}_{4}$ were further added after every 15 min with continuous stirring. For all batches, the experimental conditions (e.g., stirring speed, the size of the magnetic bar and reaction flask) were kept as similar as possible. After $1 \mathrm{~h}$, the products were extracted in the hexane layer and injected in the GC. The identity of all the products was confirmed by GC-MS.

Oxidative bromination of salicylaldehyde. Salicylaldehyde $(0.610 \mathrm{~g}, 5 \mathrm{mmol})$ was added to an aqueous solution $(20 \mathrm{~mL})$ of $\mathrm{KBr}(1.785 \mathrm{~g}, 15 \mathrm{mmol})$, followed by addition of $30 \%$ aqueous $\mathrm{H}_{2} \mathrm{O}_{2}(1.14 \mathrm{~g}, 10 \mathrm{mmol})$ in a $100 \mathrm{~mL}$ reaction flask. The catalyst $(0.0005 \mathrm{~g})$ and $70 \% \mathrm{HClO}_{4}(2.14 \mathrm{~g}, 15 \mathrm{mmol})$ were added, and the reaction mixture was stirred at room temperature $\left(20{ }^{\circ} \mathrm{C}\right)$. The addition of $\mathrm{HClO}_{4}$, however, in four equal portions during the reaction with a $45 \mathrm{~min}$ interval was necessary to improve the conversion of the substrate and to avoid decomposition of the catalyst. After $3 \mathrm{~h}$, the separated white products were extracted with $\mathrm{CH}_{2} \mathrm{Cl}_{2}$ and dried. The crude mass was dissolved in methanol and was subjected to GC. The identity of the products was confirmed as mentioned above.

Oxidation of methyl phenyl sulfide. Methylphenyl sulfide ( $0.620 \mathrm{~g}, 5 \mathrm{mmol})$ and $30 \%$ aqueous $\mathrm{H}_{2} \mathrm{O}_{2}(1.14 \mathrm{~g}, 10 \mathrm{mmol})$ were dissolved in $\mathrm{CH}_{3} \mathrm{CN}(5 \mathrm{~mL})$. After addition of $0.001 \mathrm{~g}$ catalyst (1-5) to the above solution, the reaction mixture was stirred at room temperature for $2.5 \mathrm{~h}$. During this period, the reaction products formed were analyzed using GC by withdrawing small aliquots after fixed time intervals. The identities of the reaction products were confirmed by GC-MS. 


\section{Results and discussion}

Synthesis

The four tridentate ligands $\left(\mathrm{H}_{2} \mathrm{~L}^{1-4}\right)$ used in this work are given in Scheme 1. The reaction of $\mathrm{NH}_{4} \mathrm{VO}_{3}$ with $\mathrm{H}_{2} \mathrm{~L}^{1-4}$ in a ratio of $1: 1$ in refluxing ethanol in open air affords brown colored complexes of composition $\left[\mathrm{VO}\left(\mathrm{L}^{1-4}\right) \mathrm{OEt}\right](\mathbf{1 - 4})$ in excellent yields and the same reaction in the presence of a co-ligand 4,4'-bipy affords the dimeric product, $\left[\left\{\operatorname{VO}\left(\mathrm{L}^{2}\right) \mathrm{OEt}\right\}_{2}\left(\mu-4,4^{\prime}\right.\right.$-bipy $\left.)\right]$ (5). These compounds are highly soluble in $\mathrm{CH}_{2} \mathrm{Cl}_{2}$, DMF and DMSO and sparingly soluble in $\mathrm{MeOH}$, EtOH and $\mathrm{CH}_{3} \mathrm{CN}$. All complexes are diamagnetic and nonconducting in solution.

\section{Solution phase stability}

The solution phase stability was tested over a period of $72 \mathrm{~h}$ at $25{ }^{\circ} \mathrm{C}$ for all the complexes (1-5) by electronic absorption spectral studies. All the complexes were stable and did not show any change in the electronic absorption spectra in the above incubation period (ESI Fig. S1†).

\section{Description of the X-ray structure of complexes (2 and 5)}

The observed elemental $(\mathrm{C}, \mathrm{H}, \mathrm{N})$ analytical data of all the oxidoethoxido vanadium(v) complexes are consistent with their composition. It appears from the formulation of the monomeric complexes that hydrazones serve as tridentate ligands in them. Although the preliminary characterization data (microanalysis and IR) indicated the presence of the ligand, oxido group and ethoxido group in the complexes, they could not point to any definite stereochemistry of the complexes, or the coordination mode of $\mathrm{H}_{2} \mathrm{~L}$. In order to authenticate the coordination mode of the azines in these complexes, the structure of 2 has been determined by X-ray crystallography. The atom numbering scheme for complex 2 is given in Fig. 1(a) with the relevant bond distances and angles given in ESI, Table S2. $\dagger$ In complex 2, the vanadium(v) centre is occupied by an $\mathrm{O}_{4} \mathrm{~N}$ coordination sphere, constituting a square pyramidal structure as indicated by the geometric parameter $\tau(0.13) .{ }^{42}$ The basal plane is made up of the phenolate oxygen, enolic oxygen,

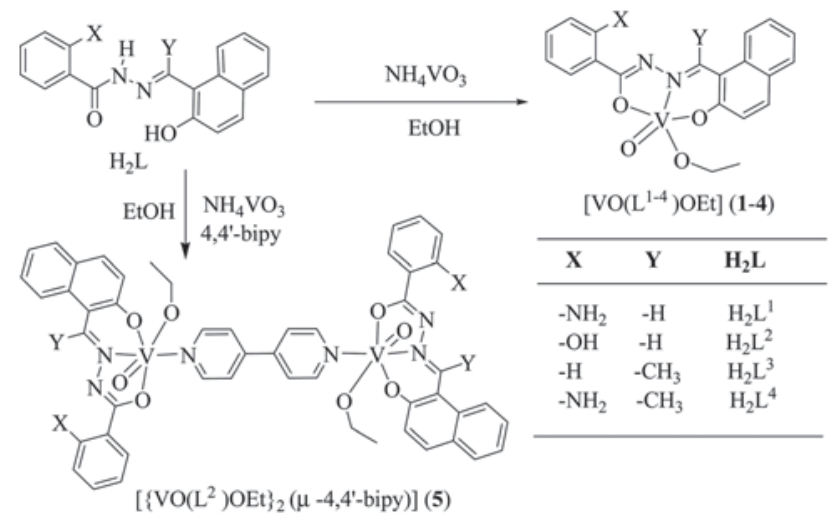

Scheme 1 Schematic diagram of various pathways through which the oxidovanadium(v) complexes (1-5) were synthesized.
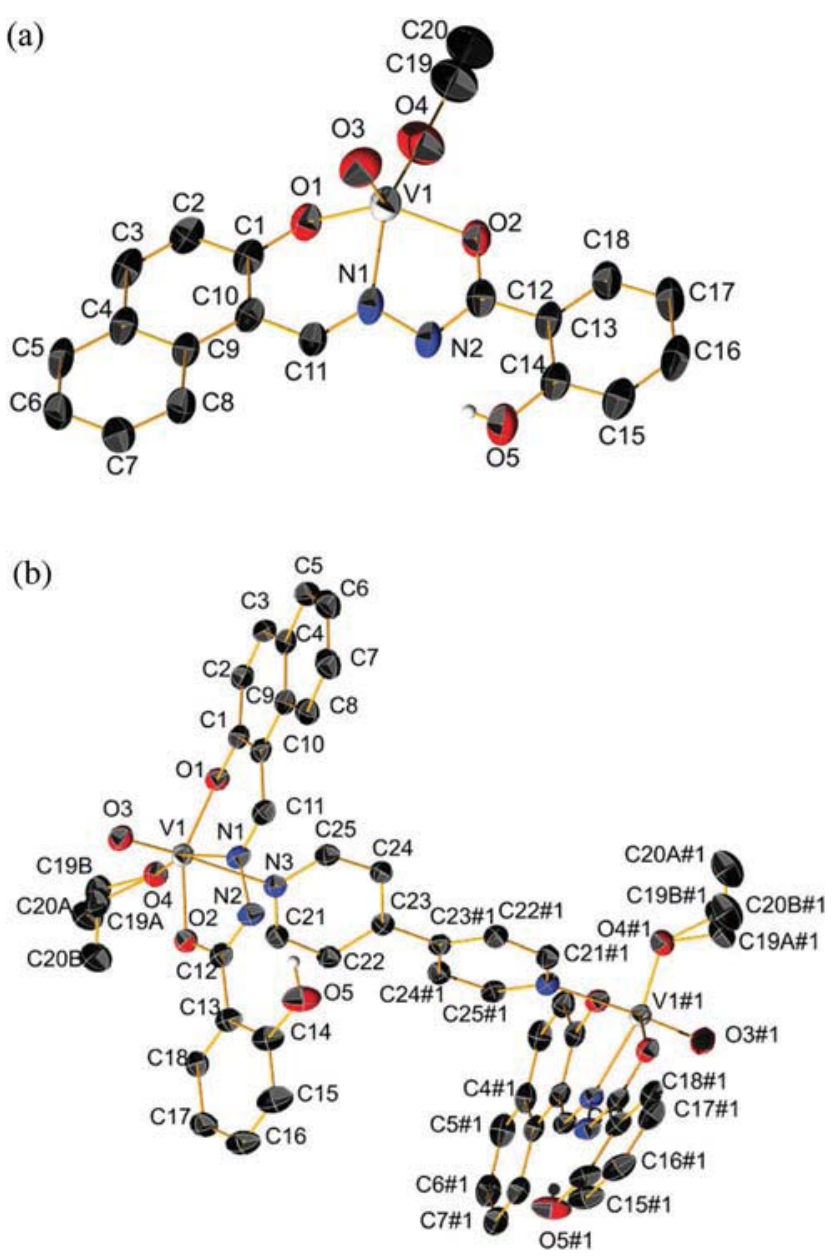

Fig. 1 ORTEP diagram of (a) $\left[\mathrm{VO}\left(\mathrm{L}^{2}\right) \mathrm{OEt}\right]$ (2), (b) $\left[\left\{\mathrm{VO}\left(\mathrm{L}^{2}\right) \mathrm{OEt}\right\}_{2}\left(\mu-4,4^{\prime}-\right.\right.$ bipy)] (5).

imine nitrogen from the ligand and the oxygen from a deprotonated alkoxide. The Schiff base ligand forms a six membered and a five membered chelate ring at the $\mathrm{V}(\mathrm{v})$ accepter centre with bite angles of $81.6(2)^{\circ}$ and $74.7(2)^{\circ}$ for $\mathrm{O}(1)-\mathrm{V}(1)-\mathrm{N}(1)$ and $\mathrm{O}(2)-\mathrm{V}(1)-\mathrm{N}(1)$ respectively. The apical position of the square pyramid is occupied by the terminal oxido group $\mathrm{O}(3)$. The short V(1)-O(3) distance, 1.581(6) ̊ indicates the presence of a vanadium oxygen double bond $(\mathrm{V}=\mathrm{O})$, which is commonly found in the five and six coordinated octahedral complexes ${ }^{43}$ of vanadium(Iv) and vanadium(v). The four $\mathrm{V}-\mathrm{O}$ bond lengths are unequal, the $\mathrm{V}=\mathrm{O}$ bond being the shortest and $\mathrm{V}-\mathrm{O}$ (enolate) being the longest. The $\mathrm{V}-\mathrm{O}$ bond length follows the order, $\mathrm{V}-\mathrm{O}$ (oxido) $<\mathrm{V}-\mathrm{O}$ (alkoxido) $<\mathrm{V}-\mathrm{O}$ ( phenolate) $<\mathrm{V}-\mathrm{O}$ (enolate). These data indicate the stronger binding of the alkoxido group compared to those of the phenolate and enolate oxygen atoms. ${ }^{43 a, b}$

The dinuclear complex, 5 (Fig. 1(b), ESI Table S2†) crystallizes in the tetragonal crystal system with a space group, $P 4 / n$, with the molecule sitting across a crystallographic center of inversion. Each half of the dinuclear complex, $\left[\left\{\mathrm{VO}\left(\mathrm{L}^{2}\right) \mathrm{OEt}\right\}_{2}\right.$ $\left(\mu-4,4^{\prime}\right.$-bipy)] (5), closely resembles the structure of the other 
half of the complex. The coordination environment around the $\mathrm{V}(\mathrm{v})$ center is octahedral and highly distorted. The ligand $\mathrm{H}_{2} \mathrm{~L}^{2}$ is dianionic and tridentate, with its meridionally situated donor sites $\mathrm{O}(1), \mathrm{N}(1)$, and $\mathrm{O}(2)$ lying in the equatorial plane along with the ethoxido oxygen $\mathrm{O}(4)$. The chelate bite angles for the five- and six-membered rings have values within the expected ranges $\left[\mathrm{O}(2)-\mathrm{V}(1)-\mathrm{N}(1), 74.87(6)^{\circ} ; \mathrm{O}(1)-\mathrm{V}(1)-\mathrm{N}(1)\right.$, $82.09(6)^{\circ}$. The bond distances about $\mathrm{V}(1)$ reveal the magnitude of the distortions, as can be seen in the ESI, Table S2. $\dagger$ The $\mathrm{V}-\mathrm{O}$ distances range from 1.601(2) $\AA$ for the oxido ligand $\mathrm{O}(3)$, located at an axial position to 1.966(1) A for the enolate oxygen $\mathrm{O}(2)$. The $\mathrm{V}(1)-\mathrm{O}(1)$ (phenolate) distance is slightly shorter at 1.853(1) A. The second axial position is occupied by a nitrogen atom of the bridging 4,4'-bipyridine ligand, which is significantly farther from the $\mathrm{V}$ center than the other five ligated atoms. V(1)-N(3), at 2.377(2) $\AA$, is undoubtedly the weakest of the six V-L bonds and consequently the most susceptible to ligand exchange.

\section{Spectral characteristics}

IR spectroscopy. The IR data of all the ligands, $\mathrm{H}_{2} \mathrm{~L}^{1-4}$, and their corresponding metal complexes, 1-5, are given in the Experimental section. The disappearance of the characteristic bands due to $-\mathrm{NH}$ and $-\mathrm{C}=\mathrm{O}$ in the ligand, and the appearance of new bands in the range of $1255-1238 \mathrm{~cm}^{-1}$ in the complexes (1-5), indicates the enolisation of these two groups forming a $=\mathrm{C}-\mathrm{O}$ bond sequence. The strong and sharp peak displayed by the complexes in the range of $1599-1567 \mathrm{~cm}^{-1}$ is likely to be associated with the $-\mathrm{C}=\mathrm{N}-\mathrm{N}=\mathrm{C}-$ moiety. ${ }^{32 a, 44}$ The presence of a sharp band in the range of $999-959 \mathrm{~cm}^{-1}$ is assigned to the $\mathrm{V}=\mathrm{O}$ stretching of an oxidoalkoxido vanadium(v) complex. $^{32 a}$

Electronic spectroscopy. The electronic spectra of 1-5 were recorded in $\mathrm{CHCl}_{3}$ and are quite similar. A representative spectrum of 3 is shown in Fig. 2. Strong absorptions in the range of $435-419 \mathrm{~nm}$ are assignable to the ligand-to-metal charge

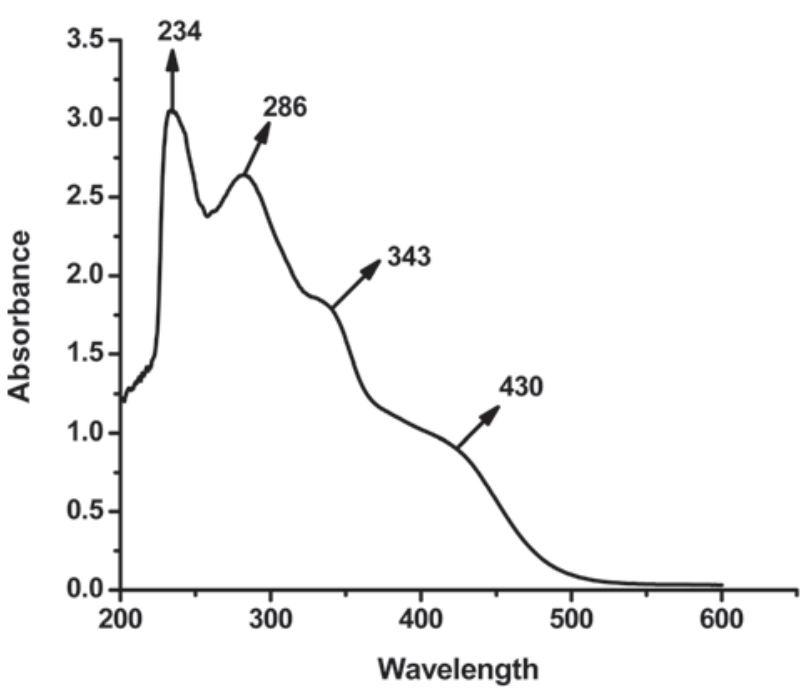

Fig. 2 UV-vis spectra of $\left[\mathrm{VO}\left(\mathrm{L}^{3}\right) \mathrm{OEt}\right](3)\left(1.20 \times 10^{-4} \mathrm{M}\right)$ in $\mathrm{CHCl}_{3}$. transfer transitions whereas the bands in the higher energy region (343-234 $\mathrm{nm}$ ) are likely to be due to ligand centred transitions. $^{31 a, 32 a}$

NMR spectroscopy. The ${ }^{1} \mathrm{H}$ and ${ }^{13} \mathrm{C}$ NMR data of the free ligands $\left(\mathrm{H}_{2} \mathrm{~L}^{1-4}\right)$ and the corresponding oxidovanadium(v) complexes (1-5) were recorded using $\mathrm{DMSO}^{-} \mathrm{d}_{6}$ and the data are given in the Experimental section. The spectra of all the ligands exhibit resonances in the range $\delta=12.97-10.31 \mathrm{ppm}$ due to naphthyl $-\mathrm{OH}$ and $\delta=12.07-9.17 \mathrm{ppm}$ due to $-\mathrm{NH}$, which disappear in the spectra of the complexes confirming deprotonation and complexation of the ligands. The presence of resonances in the range $\delta=11.61-11.59 \mathrm{ppm}$ in complexes 2 and 5 is due to the uncoordinated $-\mathrm{OH}$ present in the hydrazide part of the ligand. Complexes 1, 2 and 5 possess a resonance in the range $\delta=9.94-9.80 \mathrm{ppm}$, and complexes 3 and 4 display a singlet in the range $\delta=2.92-2.86 \mathrm{ppm}$ due to the $-\mathrm{CH}$ and $-\mathrm{CH}_{3}$ groups, respectively. All the aromatic protons of the complexes are clearly observed in the expected region, $\delta=$ 8.70-6.57 ppm.

\section{DNA binding studies}

Absorption spectroscopic studies. DNA binding affinity of the complexes 1-5 to CT-DNA was studied using various spectral techniques. The equilibrium binding constant $\left(K_{\mathrm{b}}\right)$ of the complexes to CT-DNA was determined with the aid of UV-vis titration experiments (Table 1 and Fig. 3). Complexes 1-5 exhibit absorption bands in the regions 440-400 and 340-300 $\mathrm{nm}$, which are attributed to $\mathrm{L}-\mathrm{V}(\mathrm{d} \pi)$ LMCT and intraligand transitions, respectively. ${ }^{32 a}$ The addition of the CT-DNA to the complexes 1-5 showed a hypochromic shift in both the LMCT and intra-ligands transition bands (Fig. 3). This hypochromic shift indicated the interaction of the CT-DNA with the complexes. This hypochromic shift may be due to the interaction between the ligand chromophores and the DNA bases. ${ }^{40}$ In general, the extent of hypochromism or hyperchromism observed provides a measure of the strength of binding of the complexes to CT-DNA. Among all the complexes, 3 and 4 showed a significant and drastic hypochromism. This implies that these two complexes may have a higher binding affinity towards CT-DNA than others. The equilibrium binding constant $\left(K_{\mathrm{b}}\right)$ between CT-DNA and each of the complexes 1-5 was calculated using eqn (1) (Experimental section, ESI $\dagger$ ).

The $K_{\mathrm{b}}$ values reported in Table 1 revealed that 3 has the highest binding affinity of $7.16 \times 10^{5} \mathrm{M}^{-1}$ and 1 has the lowest

Table 1 Thermodynamic data for CT-DNA binding with 1-5

\begin{tabular}{llc}
\hline Complex & Binding constant $\left(K_{\mathrm{b}}\right)^{a}\left(\mathrm{M}^{-1}\right)$ & $\Delta T_{\mathrm{m}}{ }^{b}\left({ }^{\circ} \mathrm{C}\right)$ \\
\hline $\mathbf{1}$ & $2.35 \times 10^{4}$ & -0.27 \\
$\mathbf{2}$ & $2.48 \times 10^{4}$ & 0.15 \\
$\mathbf{3}$ & $7.16 \times 10^{5}$ & -1.46 \\
$\mathbf{4}$ & $2.73 \times 10^{5}$ & -1.11 \\
$\mathbf{5}$ & $9.29 \times 10^{4}$ & 0.66
\end{tabular}

${ }^{a}$ DNA binding constants were determined by the UV-vis spectral method. ${ }^{b}$ Change in the melting temperature of CT-DNA. 

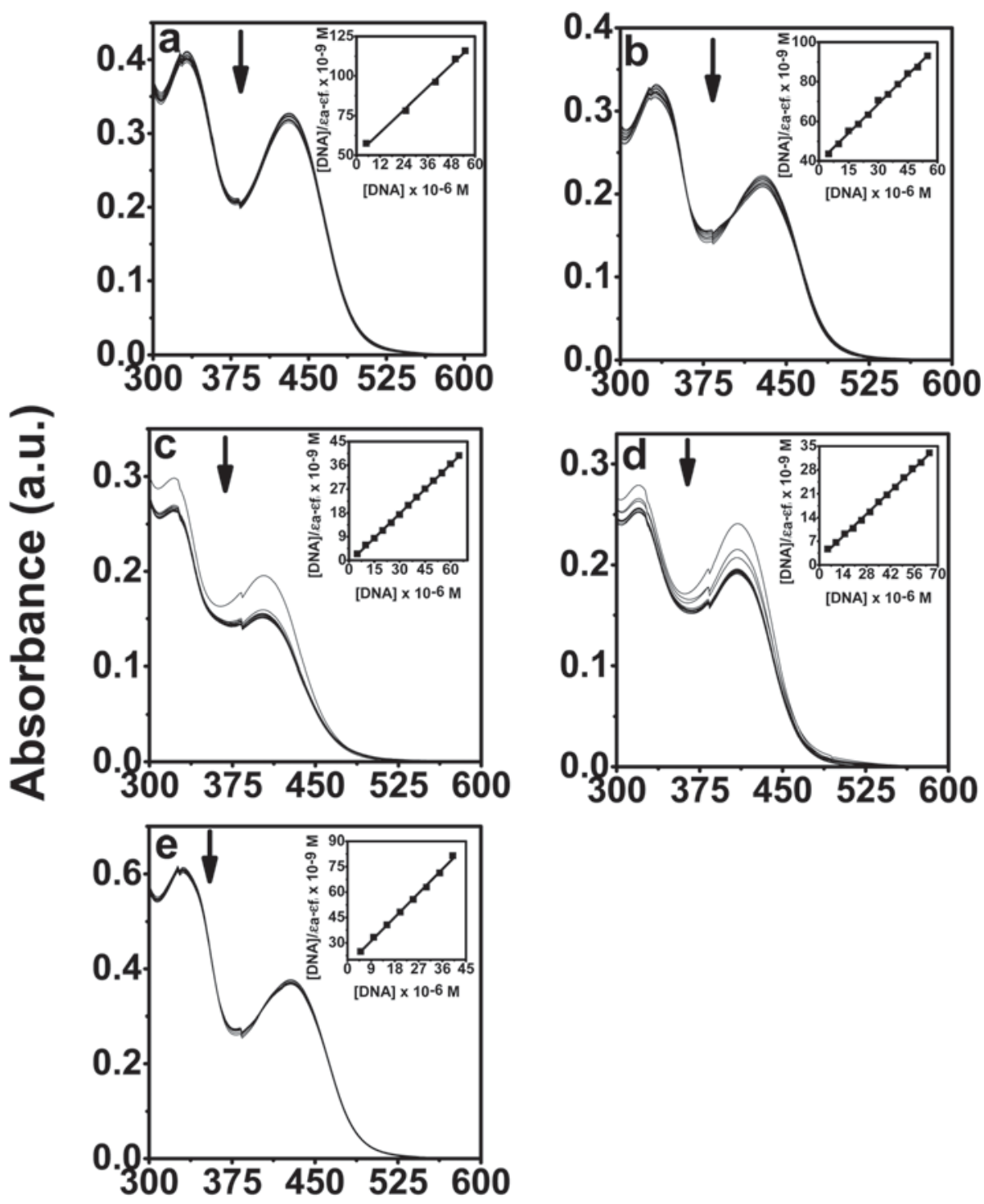

\section{Wavelength (nm)}

Fig. 3 Electronic absorption spectra of 1 (a), 2 (b), 3 (c), 4 (d) and 5 (e) $(25 \mu \mathrm{M}$ each) upon the titration of CT-DNA (0-65 $\mu \mathrm{M})$ in $10 \mathrm{mM}$ Tris-HCl buffer ( $\mathrm{pH}$ 8.0) containing 1\% DMF. Arrow shows the changes in absorbance with respect to an increase in the CT-DNA concentration. The inset shows the linear fit of $[\mathrm{DNA}] /\left(\varepsilon_{\mathrm{a}}-\varepsilon_{\mathrm{f}}\right) v$ s. [DNA] and the binding constant $\left(K_{\mathrm{b}}\right)$ was calculated using eqn (1) (Experimental section, ESI $\left.\dagger\right)$.

binding affinity of $2.35 \times 10^{4} \mathrm{M}^{-1}$ (Table 1 ). All the complexes exhibited moderate binding affinity, and the DNA binding strength of the complexes are in the order of $\mathbf{3}>\mathbf{4}>\mathbf{5}>\mathbf{2}>\mathbf{1}$ (Table 1). The binding affinity of the ligands to CT-DNA was lower than their corresponding complexes (ESI Fig. S2 and Table S3†).

Thermal denaturation studies. To understand the nature of interaction between CT-DNA and the complexes, thermal denaturation experiments were performed. The melting temperature $\left(T_{\mathrm{m}}\right)$ of CT-DNA in the absence of any complex was $64.5{ }^{\circ} \mathrm{C}$ (Fig. 4) which is quite in agreement with our previous results. ${ }^{39,40}$ The melting temperature of CT-DNA increased very slightly upon interaction with complex $\mathbf{5}$, while
1 and 2 had a negligible effect on the melting temperature of CT-DNA (Fig. 4 and Table 1). On the other hand, a decrease in the melting point of CT-DNA of about $\sim 1.5$ and $1.0{ }^{\circ} \mathrm{C}$ was observed for complex 3 and 4 respectively (Fig. 4 and Table 1). This decrease in the melting point of CT-DNA may be due to the destabilisation of a DNA double helix by these two complexes. Similar properties are also shown by wellknown alkylating agents, cisplatin and its derivatives. ${ }^{45,46}$ A small shift in the DNA melting temperature suggests that the interaction between the complexes and CT-DNA follows a groove binding mode. ${ }^{39}$

Circular dichroism studies. Circular dichrosim spectroscopy was used to explore the conformational changes in CT-DNA 


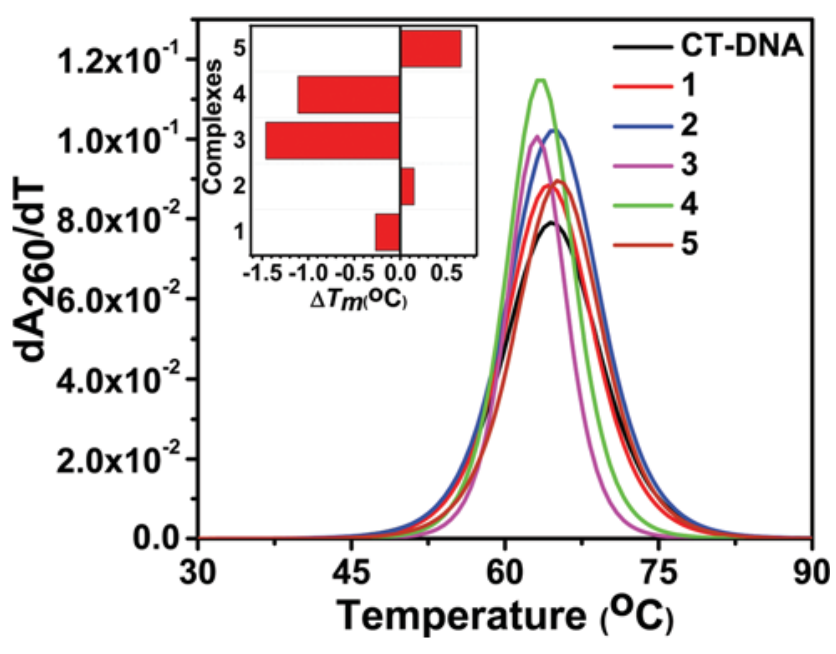

Fig. 4 Derivative plot of thermal denaturation of CT-DNA $(150 \mu \mathrm{M})$ in the absence and presence of 1-5 $(50 \mu \mathrm{M})$. The experiment was done in $10 \mathrm{mM}$ Tris- $\mathrm{HCl}$ buffer $(\mathrm{pH}$ 8.0) containing $1 \%$ DMF. Inset shows the $\Delta T_{\mathrm{m}}\left({ }^{\circ} \mathrm{C}\right)$ of the complexes as compared to CT-DNA.

due to interactions with the complexes. ${ }^{47}$ CT-DNA shows two conservative $\mathrm{CD}$ bands in the UV region at $275 \mathrm{~nm}$ (positive band) due to base stacking and at $245 \mathrm{~nm}$ (negative band) due to right handed helicity. ${ }^{47}$ Groove binding and electrostatic interaction of small molecules show less or no perturbation on the base stacking and helicity bands, whereas an intercalation mode can induce intensity changes of both bands, thus modulating the right handed B-conformation of DNA. ${ }^{47}$ The CD spectra of CT-DNA $(150 \mu \mathrm{M})$ in the presence of the complexes showed a slight increase in the negative ellipticity at $245 \mathrm{~nm}$ as well as in the positive ellipticity at $275 \mathrm{~nm}$ (ESI Fig. S3†). This CD spectral behaviour of the complexes 1-5 with CT-DNA indicated that the binding of CT-DNA to the complexes follows a groove binding mode, which is in coherence with our thermal melting studies.

Competitive binding studies. The thermal denaturation and the circular dichroism experiments hinted that the complexes 1-5 bind to CT-DNA through a groove binding mode. Therefore, in order to find out the exact binding mode of the complexes with CT-DNA, we performed competitive binding experiments with three fluorescent dyes namely DAPI, MG and EB. DAPI and MG are mainly the minor and major groove binders respectively, while EB binds to DNA through intercalation. ${ }^{39}$ The titration of the DAPI bound CT-DNA with increasing complex concentration led to the quenching of the emission intensity of the DAPI bound CT-DNA at $455 \mathrm{~nm}$ with a red shift in the emission maxima (ESI Fig. S4 $\dagger$ ). This indicated the displacement of the bound DAPI to CT-DNA by the complexes 1-5 (ESI Fig. S4†). Complex 3 exhibited the highest quenching of $\sim 90 \%$ followed by complexes 1 and 2 ( $\sim 70 \%$ ) (ESI Fig. S4 $\dagger$ ). Complexes 4 and $\mathbf{5}$ showed the lowest quenching of $\sim 53 \%$ of the fluorescence intensity at $455 \mathrm{~nm}$ (ESI Fig. S4 $\dagger$ ). Hence our data clearly showed that the complexes 1-5 bind to the CT-DNA through a minor groove binding mode.
In order to assess whether the complexes interacted with CT-DNA by major groove binding, MG bound CT-DNA was titrated with increasing concentration of the complexes. The decrease in the emission intensity of the MG bound CT-DNA at $672 \mathrm{~nm}$ upon the addition of the complexes indicated that the complexes 1-5 interacted with CT-DNA through a major groove binding mode (ESI Fig. S5 $\dagger$ ). Complex 3 showed the highest quenching of the emission intensity at $672 \mathrm{~nm}$ of $\sim 40 \%$ followed by complex 1 and 4 , which exhibited a quenching of $\sim 22$ and $\sim 27 \%$ respectively (ESI Fig. S5 $\dagger$ ). The lowest quenching of the emission intensity at $672 \mathrm{~nm}$ was shown by the complexes 2 and 5 of $\sim 16$ and $\sim 12 \%$ respectively (ESI Fig. S5 $\dagger$ ). Therefore our results clearly revealed that the complexes 1-5 interacted with CT-DNA through both major and minor groove binding modes.

Similar competitive experiments were also performed with EB bound CT-DNA. The addition of the complexes to the EB bound CT-DNA did not quench $(<2 \%)$ the emission intensity of the EB bound CT-DNA at $597 \mathrm{~nm}$ significantly (ESI Fig. S6 + ). This clearly showed that the complexes did not interact with the CT-DNA by intercalation which is in good agreement with our thermal melting and circular dichroism experiments.

\section{DNA cleavage studies}

Chemical-induced DNA cleavage. The cleavage of supercoiled (SC) pUC19 DNA (300 ng) by 1-5 (1-500 $\mu \mathrm{M})$ in the dark was done with the aid of hydrogen peroxide as the oxidising agent. The complexes do not show any apparent DNA cleavage implying that no hydrolytic cleavage activity took place. The lack of chemical nuclease activity may be due to their moderate interaction and binding with DNA.

Photo-induced DNA cleavage. In order to explore whether the DNA binding properties of the complexes 1-5 were associated with any photonuclease activity, a photo-induced DNA cleavage assay was performed. Photo-induced DNA cleavage activity of 1-5 was studied using supercoiled (SC) pUC19 DNA in $50 \mathrm{mM}$ Tris-HCl buffer ( $\mathrm{pH}$ 8.0) containing 1\% DMF upon irradiation of UVA light of $350 \mathrm{~nm}$ in the presence and absence of the complexes (ESI Fig. S7 $\dagger$ ). The extent of SC DNA cleavage by the complexes was monitored in a concentration dependent manner with the aid of agarose gel electrophoresis as shown in ESI Fig. S7. $\dagger$ The oxidoalkoxido vanadium(v) complexes showed greater than $\sim 15 \%$ DNA cleavage activity at a concentration of $5 \mu \mathrm{M}$ (Fig. 5). This cleavage activity of the complexes was almost saturated at a complex concentration of $100 \mu \mathrm{M}$ (Fig. 5, inset). Among all the complexes, 3 showed the highest DNA cleavage activity of $\sim 48 \%$, which abides well with its DNA binding parameters (Fig. 5 and Table 1), while the photoinduced cleavage activity of complexes 1, 2, 4 and 5 saturated at $\sim 36, \sim 27, \sim 34$ and $\sim 25 \%$ respectively (Fig. 5). The photonuclease activity was also carried out with $10 \mathrm{mM}$ phosphate buffer at pH 7.8 containing 1\% DMF and the DNA cleavage activity obtained was similar to the results observed for Tris buffer containing 1\% DMF. This observation is in accordance with our previous studies with oxido vanadium complexes. ${ }^{39,40}$ 


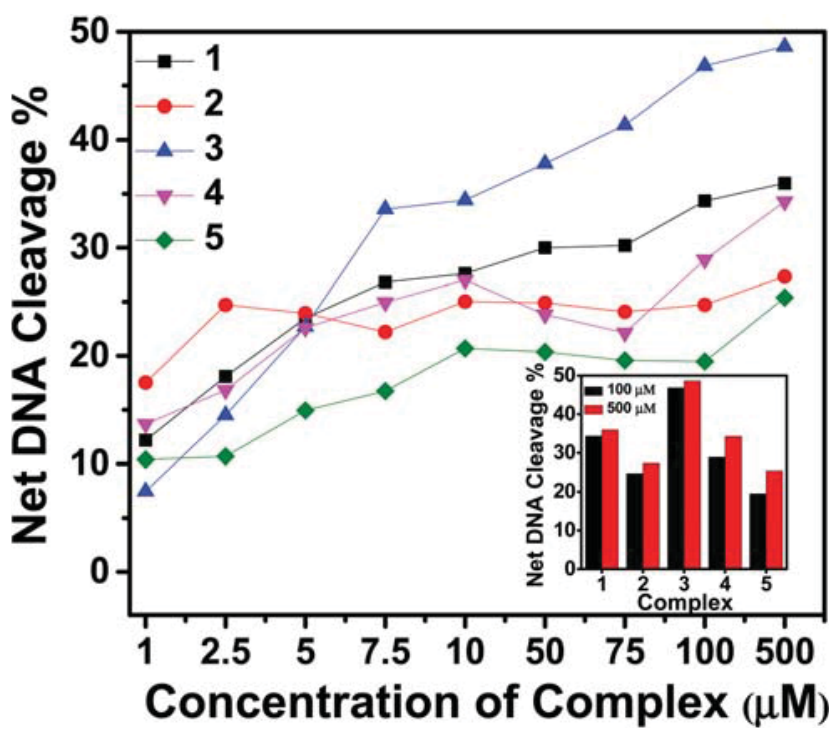

Fig. 5 Concentration dependent DNA cleavage by 1-5; $300 \mathrm{ng}$ of SC pUC19 DNA at different concentrations of the complexes [1-500 $\mu \mathrm{M}$ in $50 \mathrm{mM}$ Tris- $\mathrm{HCl}$ buffer $(\mathrm{pH} 8.0)$ containing $1 \%$ DMF] was photoirradiated with UVA at $350 \mathrm{~nm}$ for $3 \mathrm{~h}$. The net DNA cleavage percent was calculated using eqn (2) (Experimental section, ESI $\dagger$ ). Inset shows a bar diagram representation of the net DNA cleavage of different complexes at 100 and $500 \mu \mathrm{M}$

Control experiments were performed which suggest that neither DMF (1\%) nor the ligands exhibited any photoinduced DNA cleavage activity, which implies that ligands or DMF (1\%) were cleavage inactive under similar experimental conditions (ESI Fig. S8†).

In order to investigate the mechanism involved in the photonuclease reactions, the photo-induced DNA cleavage experiments of complexes 1-5 were performed in the presence of various quenchers. The DNA cleavage reaction involving molecular oxygen can proceed in two mechanistic pathways: (a) a type-II process involving singlet oxygen species $\left({ }^{1} \mathrm{O}_{2}\right)$, or (b) by a photo-redox pathway involving reactive hydroxyl radicals $(\mathrm{OH}) .{ }^{39}$ The addition of $\mathrm{NaN}_{3}$ (singlet oxygen quencher) decreased the photonuclease activity of complexes 1, 3 and 4 by $\sim 12, \sim 9$ and $\sim 6 \%$ respectively (ESI Fig. S9 and S10 $\uparrow$ ). The other singlet oxygen quencher i.e. L-histidine slightly inhibited the photo-induced DNA cleavage activity by $\sim 4-5 \%$ for complexes 1, 3 and 4 (ESI Fig. S9 and S10 $†$ ). But the DNA cleavage activity of $\mathbf{2}$ and $\mathbf{5}$ did not alter in the presence of these two additives (ESI Fig. S9 and S10 $\dagger$ ). The hydroxyl radical scavenger KI, inhibited the photonuclease activity of 1, 3 and 4 by $\sim 8$, $\sim 10$ and $\sim 8 \%$ respectively (ESI Fig. S9 and S10†). D-Mannitol decreased the DNA cleavage activity of 3 by $\sim 8 \%$, while a marginal decrease was observed for 1 and 4 (ESI Fig. S9 and S10†). However, complexes $\mathbf{2}$ and $\mathbf{5}$ did not show any inhibition in the photo-induced DNA cleavage activity in the presence of these two additives (ESI Fig. S9 and S10†). Therefore, it can be inferred that 1, 3 and $\mathbf{4}$ exhibited photo-induced DNA cleavage activity possibly via both singlet oxygen and hydroxyl radical pathways, while the mechanistic pathways involved in the photo-induced DNA cleavage of 2 and $\mathbf{5}$ cannot be stated with certainty.

\section{Protein binding and cleavage experiments}

Bovine serum albumin (BSA) binding studies. The interaction between small molecules and serum protein is a significant characteristic of metal drug metabolism and can possibly effect the biotransformation and the mechanism of action of the chemotherapeutic agents. ${ }^{48}$ BSA is often selected as a model protein to study the interaction of the small molecules with serum albumins due to its similarity with human serum albumin. ${ }^{47}$ Therefore, as the oxidoalkoxido vanadium(v) complexes showed good binding propensities towards CT-DNA and photo-induced DNA cleavage activity, further investigation of the interaction of these complexes 1-5 with bovine serum albumin (BSA) was undertaken. Qualitative analysis of the interaction of the complexes 1-5 with BSA was studied by examining the quenching of the tryptophan fluorescence emission spectra of BSA in the presence of the complexes. The fluorescence of the protein is specifically caused by three amino acid residues namely tryptophan, tyrosine and phenylalanine. BSA consists of two tryptophan residues along its amino acid sequence and exhibits tryptophan fluorescence at an excitation of $295 \mathrm{~nm}$ with an emission maximum at $344 \mathrm{~nm}$. The interaction with BSA was followed by monitoring the quenching of tryptophan fluorescence upon the addition of complexes (Fig. 6). The intrinsic tryptophan fluorescence intensity of BSA was found to quench gradually on increasing the complex concentration of 1, 2 and 5 whereas in the case of 3 and 4 there was a drastic decrease in the fluorescence intensity of tryptophan on increasing the complex concentration (Fig. 6). This shows that the binding affinity of $\mathbf{3}$ and $\mathbf{4}$ towards BSA is much greater than other complexes.

In order to quantify the binding affinity of the complexes towards BSA, the Stern-Volmer quenching constant $\left(K_{\mathrm{SV}}\right)$ was calculated using eqn (3) (Experimental section, ESI $\dagger$ ). The quenching constants for 3 and 4 were found to be $7.35 \times 10^{6}$ and $6.62 \times 10^{6} \mathrm{M}^{-1}$, respectively (Table 2), which revealed that the quenching ability of 3 and 4 is $\sim 10$ folds greater than other complexes. The quenching constant of the complexes are in the order of $\mathbf{3}>\mathbf{4}>\mathbf{5}>\mathbf{2}>\mathbf{1}$ (Table 2), which is similar to the order of the binding constant of the complexes with CT-DNA as observed earlier (Table 3). The extent of quenching of the fluorescence intensity confers a measure of association of the complex with BSA. Small molecules bind independently to a set of sites in a protein molecule, and the equilibrium between the free and the bound molecule is given by the Scatchard equation ${ }^{49}$ (eqn (4), Experimental section, ESI $\dagger$ ). The binding constant $\left(K_{\mathrm{BSA}}\right)$ and the number of binding sites (n) were obtained from the plot of $\log \left[\frac{F_{0}-F}{F}\right]$ vs. $\log [\mathrm{Q}]$ (Table 2 and ESI Fig. S11 $\dagger$ ). Both the complexes 3 and 4 showed around $10^{3}-10^{4}$ fold more binding affinity than other complexes as depicted from their binding constants of $7.60 \times$ $10^{11}$ and $1.74 \times 10^{10} \mathrm{M}^{-1}$ respectively (Table 2). The binding 

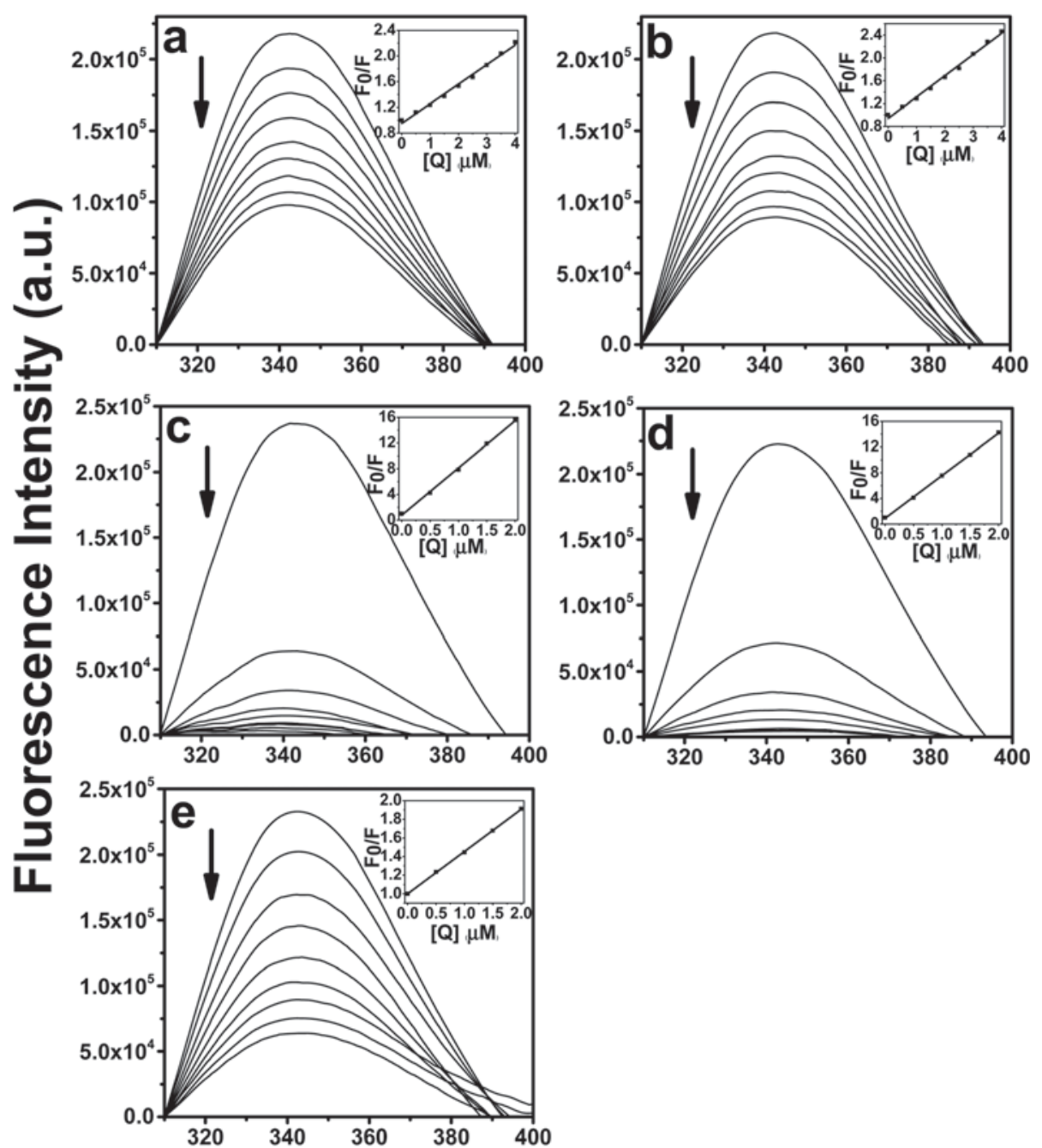

\section{Wavelength (nm)}

Fig. 6 Intrinsic tryptophan fluorescence spectra of BSA $(2 \mu \mathrm{M})$ in the presence of complex 1 (a), 2 (b), 3 (c), 4 (d) and 5 (e) $(0-4 \mu M)$. Tryptophan fluorescence spectra were recorded in the range of $310-400 \mathrm{~nm}$ at $25{ }^{\circ} \mathrm{C}$. The excitation wavelength was $295 \mathrm{~nm}$. Arrow indicates the effect of increasing concentration of complexes on the tryptophan fluorescence emission of BSA. The inset shows the linear fit of $F_{0} / F v s$. [complex] and the Stern-Volmer quenching constant $\left(K_{\mathrm{sv}}\right)$ was calculated using eqn (3) (Experimental section, ESI $\dagger$ ).

Table 2 BSA binding parameters of 1-5

\begin{tabular}{llll}
\hline Complex & $\begin{array}{l}\text { Stern Volmer } \\
\text { constant }^{a} \\
\left(K_{\mathrm{SV}}\right)\left(\mathrm{M}^{-1}\right)\end{array}$ & $\begin{array}{l}\text { Binding } \\
\text { constant }^{a} \\
\left(K_{\mathrm{BSA}}\right)\left(\mathrm{M}^{-1}\right)\end{array}$ & $\begin{array}{l}\text { Number of } \\
\text { binding }^{a} \\
\text { sites }(n)\end{array}$ \\
\hline $\mathbf{1}$ & $3.04 \times 10^{5}$ & $1.15 \times 10^{6}$ & 1.11 \\
$\mathbf{2}$ & $3.72 \times 10^{5}$ & $1.74 \times 10^{6}$ & 1.12 \\
$\mathbf{3}$ & $7.35 \times 10^{6}$ & $7.60 \times 10^{11}$ & 1.85 \\
$\mathbf{4}$ & $6.62 \times 10^{6}$ & $1.74 \times 10^{10}$ & 1.58 \\
$\mathbf{5}$ & $4.53 \times 10^{5}$ & $2.11 \times 10^{7}$ & 1.29
\end{tabular}

${ }^{a}$ Stern Volmer and binding constants were determined by fluorescence spectroscopy. constant of the complexes towards BSA also followed the same order as observed for the quenching constant (Table 2). The binding stoichiometry of BSA with complexes 3 and $\mathbf{4}$ was also found to be greater than other complexes i.e. 1:1.85 and $1: 1.58$ respectively (Table 2 ).

Photo-induced BSA cleavage activity. Previously, our group and others have shown that the vanadium complexes can exhibit photo-induced BSA cleavage activity. ${ }^{32 e, 40,50}$ Since complexes 1-5 exhibited good binding affinity towards BSA, their protein cleavage activity was investigated by the photo-induced BSA cleavage assay. The photo-induced BSA cleavage activity of these complexes in UVA light of $350 \mathrm{~nm}$ was carried out using $5 \mu \mathrm{M}$ of BSA in $10 \mathrm{mM}$ Tris-HCl buffer ( $\mathrm{pH}$ 8.0) containing $1 \%$ DMF. The BSA cleavage activity was monitored by SDS-PAGE gel electrophoresis in the presence and absence of complexes 1-5 (ESI Fig. S12†). A $50 \mu \mathrm{M}$ solution of complexes 1-5 showed 
Table 3 Conversion of styrene $(1.04 \mathrm{~g}, 10 \mathrm{mmol})$ using vanadium complexes (1-5) as a catalyst in $1 \mathrm{~h}$ of reaction time under different reaction conditions

\begin{tabular}{|c|c|c|c|c|c|c|c|c|c|c|}
\hline Entry & $\begin{array}{l}\mathrm{KBr} \\
{[\mathrm{g}(\mathrm{mmol})]}\end{array}$ & $\begin{array}{l}\mathrm{H}_{2} \mathrm{O}_{2} \\
{[\mathrm{~g}(\mathrm{mmol})]}\end{array}$ & $\begin{array}{l}\mathrm{HClO}_{4} \\
{[\mathrm{~g}(\mathrm{mmol})]}\end{array}$ & $\begin{array}{l}\text { Catalyst } \\
{[\mathrm{g}(\mathrm{mmol})]}\end{array}$ & $\begin{array}{l}\text { TOF } \\
{\left[\mathrm{h}^{-1}\right]}\end{array}$ & $\begin{array}{l}\text { Conv. } \\
{[\%]}\end{array}$ & Monobromo & Dibromo & Diol & $\begin{array}{l}\text { Other } \\
\text { products }\end{array}$ \\
\hline 1 & $1.19(10)$ & $1.14(10)$ & $1.43(10)$ & $0.0005 \mathrm{~g}$ & 1750 & 21 & 14 & 0 & 86 & 0 \\
\hline 2 & $1.19(10)$ & $1.14(10)$ & $1.43(10)$ & $0.001 \mathrm{~g}$ & 958 & 23 & 25 & 0 & 74 & 1 \\
\hline 3 & $1.19(10)$ & $1.14(10)$ & $1.43(10)$ & $0.0015 \mathrm{~g}$ & 750 & 27 & 17 & 0 & 82 & 1 \\
\hline 4 & $2.38(20)$ & $1.14(10)$ & $1.43(10)$ & $0.0005 \mathrm{~g}$ & 3166 & 38 & 13 & 0 & 86 & 1 \\
\hline 5 & $3.57(30)$ & $1.14(10)$ & $1.43(10)$ & $0.0005 \mathrm{~g}$ & 5750 & 69 & 39 & 0 & 60 & 1 \\
\hline 6 & $3.57(30)$ & $2.27(20)$ & $1.43(10)$ & $0.0005 \mathrm{~g}$ & 3916 & 47 & 9 & 0 & 90 & 1 \\
\hline 7 & $3.57(30)$ & $3.39(30)$ & $1.43(10)$ & $0.0005 \mathrm{~g}$ & 4416 & 53 & 11 & 0 & 88 & 1 \\
\hline 8 & $3.57(30)$ & $3.39(30)$ & $2.86(20)$ & $0.0005 \mathrm{~g}$ & 8167 & 98 & 30 & 2 & 67 & 1 \\
\hline 9 & $3.57(30)$ & $3.39(30)$ & $4.29(30)$ & $0.0005 \mathrm{~g}$ & 8250 & 99 & 23 & 4 & 69 & 4 \\
\hline 10 & $3.57(30)$ & $3.39(30)$ & $5.72(40)$ & $0.0005 \mathrm{~g}$ & 8250 & 99 & 17 & 8 & 74 & 1 \\
\hline $11^{\mathrm{a}}$ & $3.57(30)$ & $3.39(30)$ & $2.86(20)$ & $0.0005 \mathrm{~g}$ & 8000 & 96 & 28 & 1.4 & 69 & 1.6 \\
\hline $12^{\mathrm{b}}$ & $3.57(30)$ & $3.39(30)$ & $2.86(20)$ & $0.0005 \mathrm{~g}$ & 8000 & 96 & 28 & 1.7 & 67 & 3.3 \\
\hline $13^{\mathrm{c}}$ & $3.57(30)$ & $3.39(30)$ & $2.86(20)$ & $0.0005 \mathrm{~g}$ & 8818 & 97 & 23 & 2.3 & 74 & 0.7 \\
\hline $14^{\mathrm{d}}$ & $3.57(30)$ & $3.39(30)$ & $2.86(20)$ & $0.0005 \mathrm{~g}$ & 19600 & 98 & 33 & 2.3 & 63 & 1.7 \\
\hline 15 & $3.57(30)$ & $3.39(30)$ & $2.86(20)$ & Blank & - & 44 & 45 & 0 & 52 & 3 \\
\hline
\end{tabular}

$\mathrm{a}=\mathbf{1}, \mathrm{b}=\mathbf{2}, \mathrm{c}=\mathbf{4}$ and $\mathrm{d}=5$.

greater than $90 \%$ cleavage of BSA $(5 \mu \mathrm{M})$ with a photo irradiation of $90 \mathrm{~min}$ (ESI Fig. S12a-e, $\dagger$ lane 7). The complexes 1-5 did not exhibit any BSA cleavage activity in the dark. Control experiments done with 1\% DMF and the ligands showed that $1 \%$ DMF and ligands were cleavage inactive under similar experimental conditions.

\section{Catalytic activity studies}

Oxidative bromination of styrene. Model vanadium complexes can act as functional models of vanadium-dependent haloperoxidases in that they catalyse the oxidative bromination of organic substrates in the presence of $\mathrm{H}_{2} \mathrm{O}_{2}$ and bromide ion. ${ }^{51-53}$ During the catalytic reaction, the vanadium complex reacts with 1 or 2 equivalents of $\mathrm{H}_{2} \mathrm{O}_{2}$, and generates oxidomonoperoxido, $\left[\mathrm{VO}\left(\mathrm{O}_{2}\right)\right]^{+}$or oxido-diperoxido, $\left[\mathrm{VO}\left(\mathrm{O}_{2}\right)_{2}\right]^{-}$ species which ultimately oxidizes $\mathrm{KBr}$ to bromide species $\left(\mathrm{Br}_{2}\right.$, and/or $\mathrm{HOBr}$ ). The generated bromide species further reacts with the organic substrates with the release of a proton. The oxidoalkoxido vanadium(v) complexes reported here satisfactorily catalyse the oxidative bromination of styrene.

Oxidative bromination of styrene using alkoxido vanadium(v) complexes (1-5) as a catalyst precursor in the presence of $\mathrm{H}_{2} \mathrm{O}_{2}, \mathrm{KBr}$ and $\mathrm{HClO}_{4}$ gave mainly three products, namely, (a) 1,2-dibromo-1-phenylethane, (b) 2-bromo-1-phenylethane-1-ol and (c) 1-phenylethane-1,2-diol (Scheme 2). Some minor products (benzaldehyde, styrene epoxide, benzoic acid and 4-bromostyrene) were also detected but their overall percentage of the

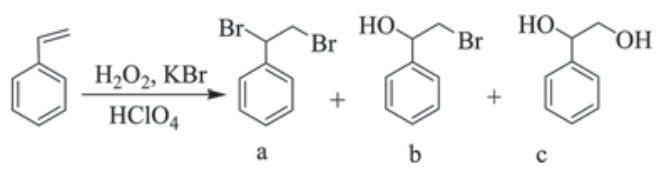

Scheme 2 Main products obtained upon oxidative bromination of styrene. (a) 1,2-Dibromo-1-phenylethane, (b) 2-bromo-1-phenylethane1-ol and (c) 1-phenylethane-1,2-diol. total of the main products was very low (ca. 4\%). Addition of $\mathrm{HClO}_{4}$ in four equal portions was required to obtain better oxidative bromination. All products were separated/isolated by column chromatography and the content of each fraction was confirmed by ${ }^{1} \mathrm{H}$ NMR spectroscopy as well as GC-MS.

The reaction was carried out at room temperature and the following parameters were studied to optimize the reaction conditions for the maximum oxidative bromination of styrene considering a representative complex 3 as a catalyst precursor: (i) amount of catalyst, (ii) amount of $\mathrm{KBr}$, (iii) amount of oxidant and (iv) amount of $\mathrm{HClO}_{4}$.

Three different amounts of 3 (0.0005, 0.0010 and $0.0015 \mathrm{~g}$ ) were used as the catalyst precursor while keeping fixed the amounts of styrene $(1.04 \mathrm{~g}, 10 \mathrm{mmol}), \mathrm{KBr}(1.19 \mathrm{~g}, 10 \mathrm{mmol})$, $30 \% \mathrm{H}_{2} \mathrm{O}_{2}(1.14 \mathrm{~g}, 10 \mathrm{mmol})$ and $70 \%$ aqueous $\mathrm{HClO}_{4}(1.43 \mathrm{~g}$, $10 \mathrm{mmol}$ ) in $\mathrm{CH}_{3} \mathrm{CN} /$ water $(20 / 5 \mathrm{~mL})$ (entries 1 to 3 of Table 3 ). Additions of $\mathrm{HClO}_{4}$ were made in four equal portions, one immediately after the catalyst precursor (reaction time $=0$ ) and the three other portions with 15 min intervals. A maximum of $21 \%$ conversion was obtained after $1 \mathrm{~h}$ of reaction with $0.0005 \mathrm{~g}$ of the catalyst, while 0.0010 and $0.0015 \mathrm{~g}$ of the catalyst did not improve the conversion much and gave $23 \%$ and $27 \%$ conversion, respectively. Therefore, $0.0005 \mathrm{~g}$ of 3 was set as optimum (Fig. 7a).

Similarly, three different substrate-to- $\mathrm{KBr}$ ratios were used (entries 4 and 5). The initial conversion of $21 \%$ with a substrate-to-KBr ratio of $1: 1$ improved to $38 \%$ upon increasing the substrate to $\mathrm{KBr}$ ratio to $1: 2$. This conversion further increased to $69 \%$ at a substrate-to- $\mathrm{KBr}$ ratio of $1: 3$. Therefore $3.57 \mathrm{~g}$ ( $30 \mathrm{mmol}$ ) of $\mathrm{KBr}$ was used for optimization of other conditions (Fig. 7b).

The effect of the amount of oxidant, added as $30 \%$ aqueous $\mathrm{H}_{2} \mathrm{O}_{2}$ solution, was studied with the substrate-to-oxidant ratios of $1: 2$ and $1: 3$ for the fixed amount of styrene (1.04 g, $10 \mathrm{mmol})$, catalyst $(0.0005 \mathrm{~g}), \mathrm{KBr}(3.57 \mathrm{~g}, 30 \mathrm{mmol})$ and $\mathrm{HClO}_{4}(1.43 \mathrm{~g}, 10 \mathrm{mmol})$ in $\mathrm{CH}_{3} \mathrm{CN} / \mathrm{H}_{2} \mathrm{O}(20 / 5 \mathrm{~mL})$, and the reaction was monitored at room temperature for $1 \mathrm{~h}$. The 

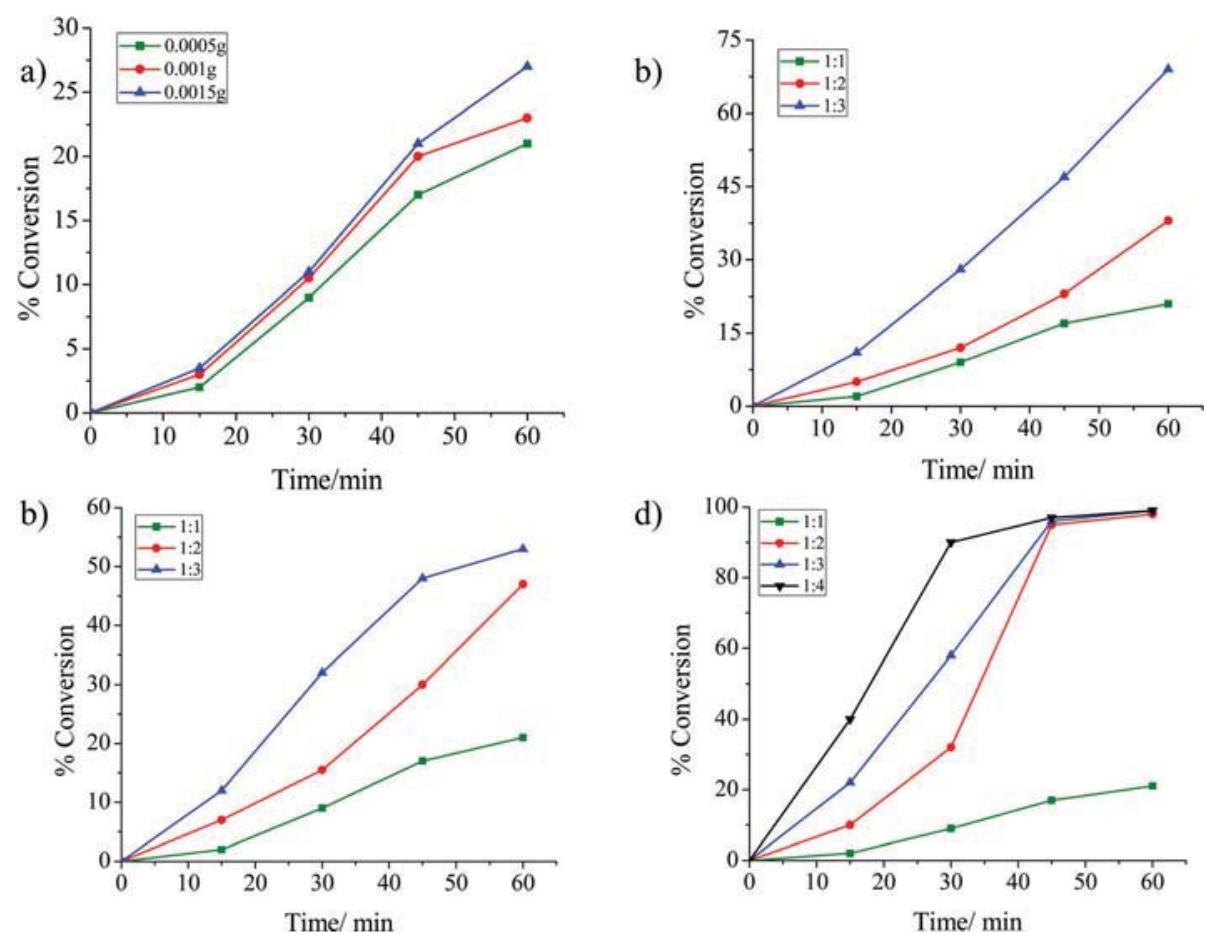

Fig. 7 (a) Effect of the catalyst amount on the oxidative bromination of styrene. Reaction conditions: styrene $(1.04 \mathrm{~g}, 10 \mathrm{mmol}), 30 \%$ aqueous $\mathrm{H}_{2} \mathrm{O}_{2}$ $(1.14,10 \mathrm{mmol}), \mathrm{KBr}(1.19 \mathrm{~g}, 10 \mathrm{mmol})$ and $70 \%$ aqueous $\mathrm{HClO}_{4}(1.43 \mathrm{~g}, 10 \mathrm{mmol})$. (b) Effect of the $\mathrm{KBr}$ amount on the oxidative bromination of styrene. Reaction conditions: styrene $(1.04 \mathrm{~g}, 10 \mathrm{mmol}), 3(0.0005 \mathrm{~g}), 30 \%$ aqueous $\mathrm{H}_{2} \mathrm{O}_{2}(1.14,10 \mathrm{mmol})$, and $70 \%$ aqueous $\mathrm{HClO}{ }_{4}(1.43 \mathrm{~g}$, $10 \mathrm{mmol})$. (c) Effect of the oxidant amount on the oxidative bromination of styrene. Reaction conditions: styrene $(1.04 \mathrm{~g}, 10 \mathrm{mmol}), 3(0.0005 \mathrm{~g}), \mathrm{KBr}$ $(3.57 \mathrm{~g}, 30 \mathrm{mmol})$ and $70 \%$ aqueous $\mathrm{HClO}_{4}(1.43 \mathrm{~g}, 10 \mathrm{mmol})$. (d) Effect of the $\mathrm{HClO}_{4}$ amount on the oxidative bromination of styrene. Reaction conditions: styrene ( $1.04 \mathrm{~g}, 10 \mathrm{mmol}), 3(0.0005 \mathrm{~g}), \mathrm{KBr}(3.57 \mathrm{~g}, 30 \mathrm{mmol})$ and $30 \%$ aqueous $\mathrm{H}_{2} \mathrm{O}_{2}(3.39,30 \mathrm{mmol})$.

conversion increased upon increasing the substrate-to-oxidant ratio, and the substrate-to-oxidant ratio of $1: 3$ gave $53 \%$ conversion of styrene (entries 6 and 7) (Fig. 7c).

To optimize the amount of $\mathrm{HClO}_{4}$, four different amounts of $70 \% \mathrm{HClO}_{4}$ were used for fixed amounts of styrene $(1.04 \mathrm{~g}$, $10 \mathrm{mmol})$, catalyst precursor $(0.0005 \mathrm{~g}), \mathrm{KBr}(3.57 \mathrm{~g}, 30 \mathrm{mmol})$, $30 \% \mathrm{H}_{2} \mathrm{O}_{2}$ (3.39 g, $\left.30 \mathrm{mmol}\right)$ and $\mathrm{CH}_{3} \mathrm{CN} /$ water $(20 / 5 \mathrm{~mL})$. Increasing the $\mathrm{HClO}_{4}$ amount from $1.43 \mathrm{~g}(10 \mathrm{mmol})$ to $2.86 \mathrm{~g}$ (20 mmol) increased the conversion from 53 to $98 \%$. Only a slight improvement in conversion was obtained upon further increasing this amount to $4.29 \mathrm{~g}$ ( $30 \mathrm{mmol}$ ) (entries 8 and 9). Therefore, $2.86 \mathrm{~g}\left(20 \mathrm{mmol}\right.$ ) of $70 \% \mathrm{HClO}_{4}$ was considered to be adequate to obtain maximum oxidative bromination of styrene (Fig. 7d).

Entry 8 of Table 3 presents the optimized reaction conditions for the oxidative bromination of $10 \mathrm{mmol}$ of styrene, which are: catalyst precursor $3(0.0005 \mathrm{~g}), 30 \%$ aqueous $\mathrm{H}_{2} \mathrm{O}_{2}$ (3.39 g, $30 \mathrm{mmol}), \mathrm{KBr}(3.57 \mathrm{~g}, 30 \mathrm{mmol}), 70 \%$ aqueous $\mathrm{HClO}_{4}$ $(2.86 \mathrm{~g}, 20 \mathrm{mmol}$ ) (added in four equal portions in $15 \mathrm{~min}$ intervals), and $\mathrm{CH}_{3} \mathrm{CN} / \mathrm{H}_{2} \mathrm{O}(20 / 5 \mathrm{~mL})$ at room temperature for $1 \mathrm{~h}$.

Catalytic activities of other complexes (1, 2, 4 and 5) have also been carried out under similar reaction conditions and are presented in Table 3 (entries 11 to 14). The catalytic potential of all complexes has been found to be equal (ESI Fig. S13†) indicating no effect of substituents $\left(-\mathrm{H},-\mathrm{NH}_{2}\right.$ and $\left.-\mathrm{OH}\right)$ on the benzene ring on their activity. The control experiment (without the catalyst) shows only $44 \%$ conversion under the above optimized conditions (entry 15 of Table 3). Fig. 8 represents the consumption of styrene and the selectivity of the

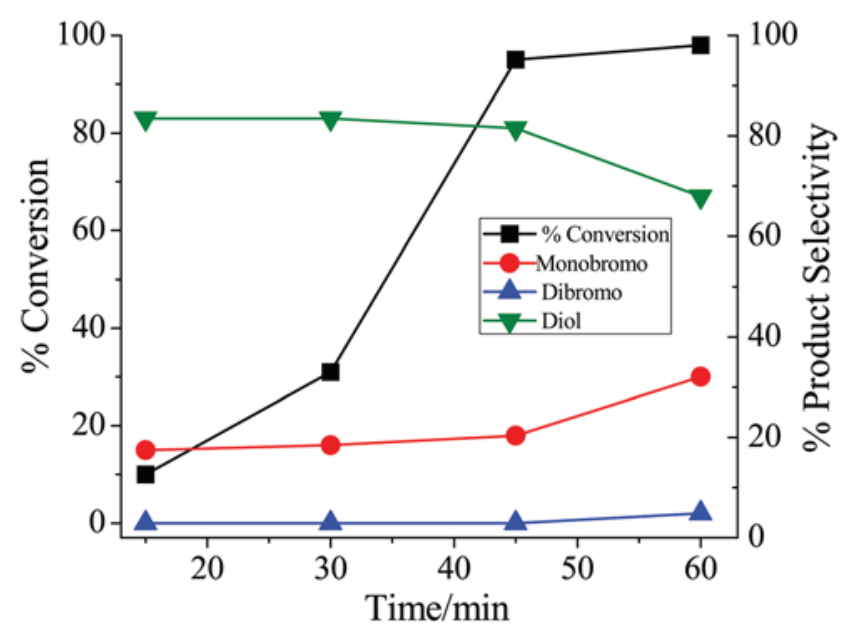

Fig. 8 Plots showing percentage conversion of styrene and the selectivity of the formation of different reaction products as a function of time. Reaction conditions: styrene $(1.04 \mathrm{~g}, 10 \mathrm{mmol}), 3(0.0005 \mathrm{~g}), 30 \%$ aqueous $\mathrm{H}_{2} \mathrm{O}_{2}(3.39,30 \mathrm{mmol}), \mathrm{KBr}(3.57 \mathrm{~g}, 30 \mathrm{mmol})$ and $70 \%$ aqueous $\mathrm{HClO}_{4}(2.86 \mathrm{~g}, 20 \mathrm{mmol})$. 


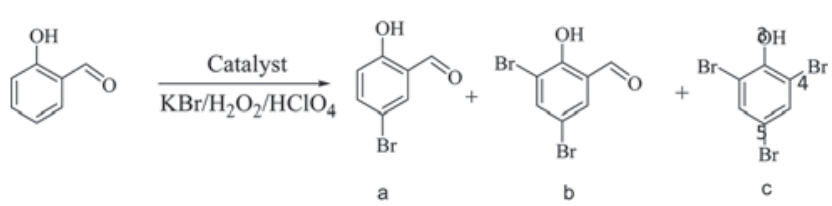

Scheme 3 Main products obtained upon oxidative bromination of salicylaldehyde. (a) 5-Bromosalicylaldehyde, (b) 3,5-dibromosalicylaldehyde and (c) 2,4,6-tribromophenol.

formation of major products with time under these experimental conditions.

Oxidative bromination of salicylaldehyde. Vanadium(v) complexes also catalyze the oxidative bromination of salicylaldehyde in the presence of $\mathrm{H}_{2} \mathrm{O}_{2}$. In the present study, complexes 1-5 were used as catalyst precursors with water as the solvent. The catalytic oxidative bromination of salicylaldehyde gave 5-bromosalicylaldehyde, 3,5-dibromosalicylaldehyde and 2,4,6tribromophenol (Scheme 3).

The oxidative bromination of salicylaldehyde was performed under different reaction conditions (Table S4 $\dagger$ ) and the maximum conversion was observed for the following conditions: salicylaldehyde $(0.610 \mathrm{~g}, 5 \mathrm{mmol})$, catalyst $(0.0005 \mathrm{~g})$, $\mathrm{KBr}(1.78 \mathrm{~g}, 15 \mathrm{mmol}), 30 \%$ aqueous $\mathrm{H}_{2} \mathrm{O}_{2}(1.14 \mathrm{~g}, 10 \mathrm{mmol})$, $70 \%$ aqueous $\mathrm{HClO}_{4}(2.14 \mathrm{~g}, 15 \mathrm{mmol})$ and water $(20 \mathrm{~mL})$ (entry 7, Table $\mathrm{S} 4 \dagger$ ); the addition of $\mathrm{HClO}_{4}$, however, in four equal portions during the reaction was necessary to improve the conversion of the substrate and to avoid decomposition of the catalyst. Under the above conditions, a maximum of $99 \%$ conversion was achieved with 3 as the representative and the selectivity of different products follows the order: 5-bromosalicylaldehyde (74\%), 2,4,6-tribromophenol (21\%) > 3,5-dibromosalicylaldehyde (5\%). Table 4 also provides \% conversion of salicylaldehyde and selectivity of the products obtained by other catalysts $(\mathbf{1}, \mathbf{2}, \mathbf{4}, \mathbf{5})$ under the above reaction conditions and is comparable to 3 .

In the absence of the catalyst, the reaction mixture gave only $c a .37 \%$ conversion of salicylaldehyde with the selectivity order of products: 5-bromosalicylaldehyde (89\%) > 2,4,6tribromophenol $(10.5 \%)>3$,5-dibromosalicylaldehyde $(0.5 \%)$.

Oxidation of methyl phenyl sulfide. Sulfoxides and sulfone, the oxidation product of sulfides, are useful precursors for biologically and chemically important compounds ${ }^{54,55}$ used in various chemical reactions. Vanadium dependent haloperoxi-

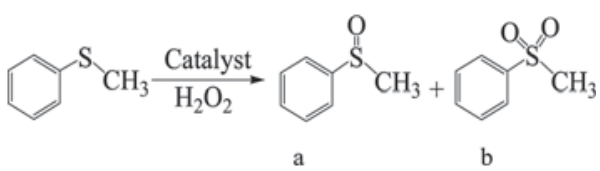

Scheme 4 Main products obtained upon oxidation of methyl phenyl sulfide. (a) Methyl phenyl sulfoxide and (b) methyl phenyl sulfone.

dases $^{1 a, 29 c}$ and model complexes catalyse the oxidation of sulfides (thioethers) to sulfoxides and further to sulfones ${ }^{30 a, 52}$ by $\mathrm{H}_{2} \mathrm{O}_{2}$. Such oxidation of methyl phenyl sulfide was tested using complexes 1-5 as the catalyst, and the corresponding oxidation products were obtained as shown in Scheme 4.

The reaction conditions were optimized for the maximum oxidation of methyl phenyl sulfide by studying three different parameters viz. the catalyst (amount of catalyst per mole of methyl phenyl sulfide), the effect of amount of oxidant (moles of $\mathrm{H}_{2} \mathrm{O}_{2}$ per mole of methyl phenyl sulfide) and the solvent of the reaction mixture in detail. The conversions obtained with all these conditions, plotted as a function of time, are presented in ESI Fig. S14(a)-(c) †. Thus for $5 \mathrm{mmol}(0.620 \mathrm{~g})$ of methyl phenyl sulfide, the amount of catalyst $(0.0005 \mathrm{~g}$, $0.001 \mathrm{~g}$ and $0.0015 \mathrm{~g}), 30 \%$ aqueous $\mathrm{H}_{2} \mathrm{O}_{2}$ (5, 10 and $\left.15 \mathrm{mmol}\right)$ and solvent $\left(\mathrm{CH}_{3} \mathrm{CN}\right)$ volume $(5,10$ and $15 \mathrm{~mL})$ were varied and the reaction was carried out at room temperature. Table S5 $\uparrow$ summarizes all conditions and conversion obtained under particular conditions taking $\mathbf{3}$ as the representative catalyst. The optimized reaction conditions for the sulfoxidation of methyl phenyl sulfide, to obtain the maximum conversion (94\%) was concluded as: methyl phenyl sulfide (0.620 g, $5 \mathrm{mmol}), 3(0.001 \mathrm{~g}), 30 \%$ aqueous $\mathrm{H}_{2} \mathrm{O}_{2}(1.14 \mathrm{~g}, 10 \mathrm{mmol})$ and $\mathrm{CH}_{3} \mathrm{CN}(5 \mathrm{~mL})$ [entry 2 of Table $\mathrm{S} 5 \dagger$ ]. The effect of different catalysts (1-5) on the oxidation of methyl phenyl sulfide is presented in ESI Fig. S14. $\dagger$

The percent conversion of methyl phenyl sulfide under the optimised reaction conditions and the selectivity of reaction products as a function of time are shown in Fig. 9. It is clear from the plot that both the products start to form with the conversion of methyl phenyl sulfide. However, the initial selectivity of $96 \%$ for methyl phenyl sulfoxide at $33.6 \%$ conversion of methyl phenyl sulfide in the first half an hour starts to decrease and reaches $65 \%$ after $2.5 \mathrm{~h}$ of reaction time. Thus, the initially formed sulfoxide further reacts with $\mathrm{H}_{2} \mathrm{O}_{2}$ present

Table 4 Effect of different catalysts (1-5) on the oxidative bromination of salicyldehyde, TOF and product selectivity

\begin{tabular}{|c|c|c|c|c|c|}
\hline \multirow[b]{2}{*}{ Catalyst (g) } & \multirow[b]{2}{*}{ TOF $\left(\mathrm{h}^{-1}\right)$} & \multirow[b]{2}{*}{$\%$ Conversion } & \multicolumn{2}{|l|}{ \% Selectivity } & \multirow[b]{2}{*}{ Tribromo } \\
\hline & & & Monobromo & Dibromo & \\
\hline 1 & 1375 & 99 & 71 & 0.6 & 28.4 \\
\hline 2 & 1375 & 99 & 68 & 7 & 25 \\
\hline 3 & 1375 & 99 & 74 & 5 & 21 \\
\hline 4 & 1500 & 99 & 71 & 0.5 & 28.5 \\
\hline 5 & 3300 & 99 & 67 & 3 & 30 \\
\hline Blank reaction & - & 37 & 89 & 0.5 & 10.5 \\
\hline
\end{tabular}




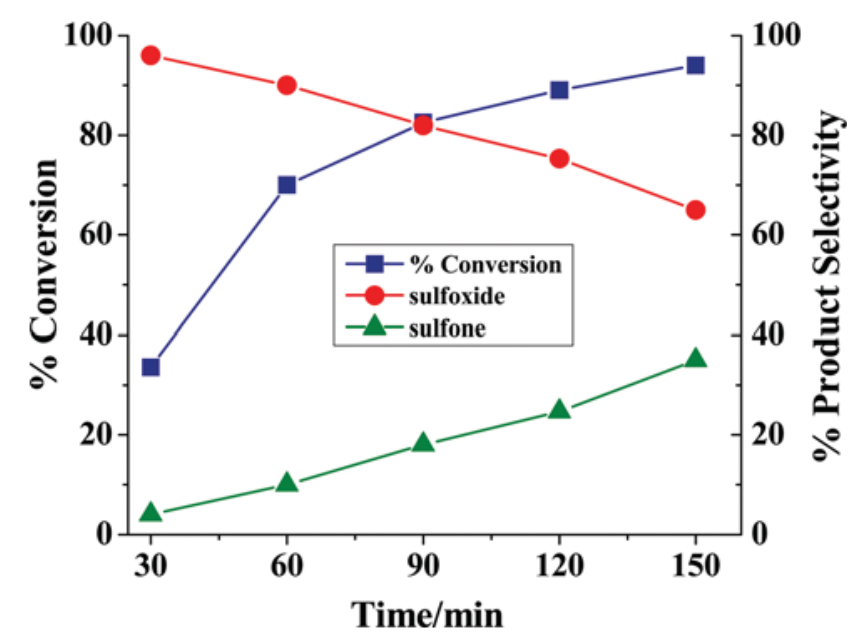

Fig. 9 Plots showing percentage conversion of methyl phenyl sulfide and the selectivity of the formation of methyl phenyl sulfoxide and methyl phenyl sulfone as a function of time under optimized conditions using 3 as the catalyst.

Table 5 Oxidation of methyl phenyl sulfide, conversion, TOF and product selectivity using $\mathbf{1 - 5}$ as the catalyst

\begin{tabular}{lllll}
\hline & & & \multicolumn{2}{l}{ Selectivity $^{b}[\%]$} \\
\cline { 4 - 5 } Catalyst & $\operatorname{TOF}^{a}\left[\mathrm{~h}^{-1}\right]$ & Conv. [\%] & mpso & mpsn \\
\hline $\mathbf{1}$ & 800 & 96 & 63.5 & 36.5 \\
$\mathbf{2}$ & 775 & 93 & 66.6 & 33.4 \\
$\mathbf{3}$ & 783 & 94 & 65 & 35 \\
$\mathbf{4}$ & 835 & 96.2 & 66.7 & 33.3 \\
$\mathbf{5}$ & 1960 & 98 & 66 & 34 \\
Blank reaction & - & 20 & 79 & 21
\end{tabular}

${ }^{a}$ TOF values calculated at $2.5 \mathrm{~h}$ of reaction time. ${ }^{b}$ mpso; methyl phenyl sulfoxide; mpsn: methyl phenyl sulfone.

in the reaction mixture to give sulfone with $35 \%$ selectivity at the end of $2.5 \mathrm{~h}$.

Other catalysts $\mathbf{1}, \mathbf{2}, \mathbf{4}$ and $\mathbf{5}$, tested under the above optimized reaction conditions gave maxima of 96\%, 93\%, 96.2\% and $98 \%$ conversion, respectively. Thus, amongst the other complexes, the catalytic efficiency varies in the order: $5>\mathbf{4}>\mathbf{1}$ $>3>2$. The selectivity of different products along with the conversion and turn over frequency for these catalysts are presented in Table 5. It is clear from the data of the table that the percent selectivity of the product, methyl phenyl sulfoxide is nearly the same but higher than methyl phenyl sulfone, in all cases.

\section{Conclusions}

The study of DNA/BSA interaction and the catalytic potential of four mononuclear oxidoethoxido vanadium $(\mathrm{v})\left[\mathrm{V}^{\mathrm{V}} \mathrm{O}\left(\mathrm{L}^{1-4}\right) \mathrm{OEt}\right]$ (1-4) and one dinuclear oxidoethoxido mixed-ligand vanadium(v) $\left[\left\{\mathrm{VO}\left(\mathrm{L}^{2}\right) \mathrm{OEt}\right\}_{2}(\mathrm{Q})\right]\left\{\mathrm{Q}=4,4^{\prime}\right.$-bipyridine $\}(5)$ complexes, with tri- dentate binegative aroylazine ligands are reported. Single crystal X-ray diffraction crystallography of 2 reveals that the metal centre is in distorted square pyramidal geometry with $\mathrm{O}_{4} \mathrm{~N}$ coordination spheres, whereas 5 exhibits a distorted octahedral geometry with $\mathrm{O}_{4} \mathrm{~N}_{2}$ coordination spheres around the metal center. The oxidoalkoxido vanadium(v) complexes (1-5) show moderate DNA binding propensity. Among 1-5, complexes 3 and 4 show a higher binding affinity towards CT-DNA than others and at the same time also exhibit negative $\Delta T_{\mathrm{m}}$ values of about $\sim 1.5$ and $1.0{ }^{\circ} \mathrm{C}$ which resembles the property shown by cisplatin.

All complexes show moderate photo-induced cleavage of pUC19 supercoiled plasmid DNA with complex 3 showing the highest photo induced DNA cleavage activity of $\sim 48 \%$. Among 1-5, complexes 1, 3 and 4 exhibit photo-induced DNA cleavage activity possibly via both singlet oxygen and hydroxyl radical pathways, while the mechanistic pathways involved in the photo-induced DNA cleavage of 2 and 5 could not be determined. In coherence with the DNA interaction studies, $\mathbf{3}$ and $\mathbf{4}$ also exhibit good binding affinity towards BSA in the range of $10^{10}-10^{11} \mathrm{M}^{-1}$ which is around $10^{3}-10^{4}$ fold more than other complexes. This behaviour is also supported by the ability of 3 and 4 to quench the tryptophan fluorescence emission spectra of BSA, which is $\sim 10$ folds greater than other complexes All the complexes show remarkable photo-induced BSA cleavage activity $(>90 \%)$ at a complex concentration of $50 \mu \mathrm{M}$. The catalytic potential of 1-5 is also tested for the oxidative bromination of styrene, salicylaldehyde and oxidation of methyl phenyl sulphide. In all the cases the percentage of conversion is increased significantly in the presence of catalysts and show high a percentage of conversion (>90\%) with a high turnover frequency. Particularly, in the oxidative bromination of styrene, the percentage of conversion and TOF varies from $96-98 \%$ and 8000-19600 $\left(\mathrm{h}^{-1}\right)$ respectively. Moreover in all the catalytic reactions 5 shows the highest TOF value. In view of the above results, it can be predicted that these oxidovanadium(v) complexes under study may have the potential to stimulate research for synthesis of a better catalyst. However, further work is in progress to correlate the catalytic efficiency of these oxidoalkoxido vanadium(v) complexes to their biological potential.

\section{Acknowledgements}

Funding for this research was provided by the Department of Science and Technology, India [grant SR/WOS-A/CS-145/2011 (SPD), grant SR/FT/CS-016/2008 (RD)] and the Council of Scientific and Industrial Research, India [grant 37(1535)/12/ EMR-II) (AB)]. AKP acknowledges the receipt of a fellowship from ICMR, India [grant 45/25/2012-Bio/BMS].

\section{Notes and references}

1 (a) D. Rehder, Bioinorganic Vanadium Chemistry, Wiley, Chichester, UK, 2008; (b) Vanadium: The Versatile Metal, 
ed. K. Kustin, J. C. Pesssoa and D. C. Crans, ACS Symposium Series 974, American Chemical Society, Washington, DC, 2007; (c) A. S. Tracey, G. R. Willsky and E. S. Takeuchi, Vanadium Chemistry, Biochemistry, Pharmacology and Practical Applications, CRC Press, Boca Raton, FL, 2007; (d) D. C. Crans, J. J. Smee, E. Gaidamauskas and L. Yang, Chem. Rev., 2004, 104, 849; (e) J. J. R. Fraústo da Silva and R. J. P. Williams, The Biological Chemistry of the Element, Oxford University Press, Oxford, UK, 2001; $(f)$ A. Mueller, F. Peters, M. T. Pope and D. Gatteschi, Chem. Rev., 1998, 98, 849.

2 M. Henze, Hoppe-Seyler's Z. Physiol. Chem., 1911, 72, 494.

3 R. L. Robson, R. R. Eady, T. H. Richardson, R. W. Miller, M. Hawkins and J. R. Postgate, Nature, 1986, 322, 388.

4 (a) H. Vilter, Photochemistry, 1984, 23, 1387; (b) E. de Boer, Y. van Kooky, M. G. M. Tromp, H. Plat and R. Waver, Biochim. Biophys. Acta, 1986, 869, 48; (c) A. Butler and J. V. Walker, Chem. Rev., 1993, 93, 1937.

5 A. A. Antipov, D. Y. Sorokin, N. P. L'Vov and J. G. Kuenen, J. Biochem., 2003, 369, 185.

6 H. Kneifel and E. Bayer, J. Am. Chem. Soc., 1986, 108, 3075.

7 R. E. Berry, E. M. Armstrong, R. L. Beddoes, D. Collison, S. N. Ertok, M. Helliwell and C. D. Garner, Angew. Chem., Int. Ed., 1999, 38, 795.

8 R. A. Coulombe, D. P. Briskin, R. J. Keller, W. R. Thornley and R. P. Sharma, Arch. Biochem. Biophys., 1987, 255, 267.

9 (a) Y. Wei, C. Zhang, P. Zhao, X. Yang and K. Wang, J. Inorg. Biochem., 2011, 105, 1081; (b) D. Rehder, J. C. Pessoa, C. F. G. C. Geraldes, T. Kabanos, T. Kiss, B. Meier, G. Micera, L. Pettersson, M. Rangel, A. Salifoglou, I. Turel and D. Wang, J. Biol. Inorg. Chem., 2002, 7, 384; (c) M. Sutradhar, T. R. Barman, G. Mukherjee, M. Kar, S. S. Saha, M. G. B. Drew and S. Ghosh, Inorg. Chim. Acta, 2011, 368, 13; (d) A. R. Saltiel and C. R. Khan, Nature, 2001, 414, 799; (e) P. Noblía, E. J. Baran, L. Otero and D. Gambino, Eur. J. Inorg. Chem., 2004, 322; (f) J. Nilsson, A. A. Shteinman, D. Rehder and E. J. Nordlander, Inorg. Biochem., 2011, 105, 1795; $(g)$ G. R. Willsky, L.-H. Chi, Z. Hu and D. C. Crans, Coord. Chem. Rev., 2011, 255, 2258; $(h)$ D. Rehder, Inorg. Chem. Commun., 2003, 6, 604; (i) M. N. Islam, A. A. Kumbhar, A. S. Kumbhar and B. N. Joshi, Inorg. Chem., 2010, 49, 8237; (j) S. I. Pillai, S. P. Subramanian and M. Kandaswamy, Eur. J. Med. Chem., 2013, 63, 109.

10 S. Ramanadham, J. J. Mongold, R. W. Brownsey, G. H. Cros and J. H. McNeill, Am. J. Physiol., 1989, 257, H904.

11 J. H. McNeill, V. G. Yuen, H. R. Hoveyda and C. Orvig, J. Med. Chem., 1992, 35, 1489.

12 J. M. Arber, E. deBoer, C. D. Garner, S. S. Hasnain and R. Wever, Biochemistry, 1989, 28, 7968.

13 A. Messerschmidt and R. Wever, Proc. Natl. Acad. Sci. U. S. A., 1996, 93, 392.

14 (a) N. Butenko, A. I. Tomaz, O. Nouri, E. Escribano, V. Moreno, S. Gama, V. Ribeiro, J. P. Telo, J. C. Pesssoa and I. Cavaco, J. Inorg. Biochem., 2009, 103, 622; (b) Y. Fu, Q. Wang, X. G. Yang, X. D. Yang and K. Wang, J. Biol. Inorg. Chem., 2008, 13, 1001.
15 N. H. Khan, N. Pandya, N. C. Maity, M. Kumar, R. M. Patel, R. I. Kureshy, S. H. R. Abdi, S. Mishra, S. Das and H. C. Bajaj, Eur. J. Med. Chem., 2011, 46, 5074.

16 (a) W. Qian, Y. Zheng-Yin, Q. Gao-Fei and Q. Dong-Dong, BioMetals, 2009, 22, 927; (b) S. R. Dalton, S. Glazier, B. Leung, S. Win, C. Megatulski and S. J. N. Burgmayer, JBIC, J. Biol. Inorg. Chem., 2008, 13, 1133; (c) Y. T. Sun, S. Y. Bi, D. Q. Song, C. Y. Qiao, D. Mu and H. Q. Zhang, Sens. Actuators, B, 2008, 129, 799.

17 (a) Y. Xiong and L. N. Ji, Coord. Chem. Rev., 1999, 185, 711; (b) D. S. Sigman, A. Mazumder and D. M. Perrin, Chem. Rev., 1993, 93, 2295; (c) E. M. Boon, J. K. Barton, P. I. Pradeepkumar, J. Isaksson, C. Petit and J. Chattopadhyaya, Angew. Chem., Int. Ed., 2002, 41, 3402; (d) C. Metcalfe and J. A. Thomas, Chem. Soc. Rev., 2003, 32, 215; (e) S. Ray, R. Mohan, J. K. Singh, M. K. Samantaray, M. M. Shaikh, D. Panda and P. Ghosh, J. Am. Chem. Soc., 2007, 129, 15042.

18 S. Sharma, S. K. Singh, M. Chandra and D. S. Pandey, J. Inorg. Biochem., 2005, 99, 458.

19 (a) K. Karami, M. Hosseini-Kharat, H. Sadeghi-Aliabadi, J. Lipkowski and M. Mirian, Eur. J. Med. Chem., 2014, 73, 8; (b) V. Mahalingam, N. Chitrapriya, F. R. Fronczek and K. Natarajan, Polyhedron, 2008, 27, 2743.

20 J. Flarakos, K. L. Morand and P. Vouros, Anal. Chem., 2005, 77, 1345.

21 (a) X. Shi and N. S. Dalal, Free Radical Res., 1992, 17, 369; (b) C. Djordjevic and G. L. Wampler, J. Inorg. Biochem., 1985, 25, 51; (c) H. Sakurai, Environ. Health Perspect., 1994, 3,35 .

22 S. Du, J. Feng, X. Lu and G. Wang, Dalton Trans., 2013, 42, 9699.

23 (a) T. S. SmithII and V. L. Pecoraro, Inorg. Chem., 2002, 41, 6754; (b) A. Butler and M. Sandy, Nature, 2009, 460, 848; (c) J. M. Winter and B. S. Moore, J. Biol. Chem., 2009, 284, 18577; (d) P. Bernhardt, T. Okino, J. M. Winter, A. Miyanaga and B. S. Moore, J. Am. Chem. Soc., 2011, 133, 4268; (e) C. G. Werncke, C. Limberg, C. Knispel, R. Metzinger and B. Braun, Chem. - Eur. J., 2011, 17, 2931.

24 J. A. L. Silva, J. J. R. Fraústo da Silva and A. J. L. Pombeiro, Coord. Chem. Rev., 2011, 255, 2232.

25 (a) L. Gonzalez Cuervo, Y. N. Kozlov, G. S€uss-Fink and G. B. Shul'pin, J. Mol. Catal. A: Chem., 2004, 218, 171; (b) V. N. Shetti, M. J. Rani, D. Srinivas and P. Ratnasamy, J. Phys. Chem. B, 2006, 110, 677; (c) T. K. Si, S. Chakraborty, A. K. Mukherjee, M. G. B. Drew and R. Bhattacharyya, Polyhedron, 2008, 27, 2233; (d) X. Wei, L. Ye and Y. Yuan, J. Nat. Gas Chem., 2009, 18, 295; (e) P. Borah and A. Datta, Appl. Catal., A, 2010, 376, 19; (f) S. M. de Lima, J. A. Gómez, V. P. Barros, G. de S. Vertuan, M. das Dores Assis, C. F. de Oliveira Graeff and G. J.-F. Demets, Polyhedron, 2010, 29, 3008; $(g)$ A. Pokutsa, Y. Kubaj, A. Zaborovskyi, D. Maksym, J. Muzart and A. Sobkowiak, Appl. Catal., A, 2010, 390, 190.

26 (a) M. R. Maurya, A. Arya, P. Adão and J. Costa Pessoa, Appl. Catal., A, 2008, 351, 239; (b) C. F. Marchetti, C. Pettinari, 
C. Di Nicola, R. Pettinari, A. Crispini, M. Crucianelli and A. Di Giuseppe, Appl. Catal., A, 2010, 378, 211; (c) M.-C. Hsiao and S.-T. Liu, Catal. Lett., 2010, 139, 61.

27 (a) T. K. Si, K. Chowdhury, M. Mukherjee, D. C. Bera and R. Bhattacharyya, J. Mol. Catal. A: Chem., 2004, 219, 241; (b) P. M. Reis, J. A. L. Silva, J. J. R. Fraústo da Silva and A. J. L. Pombeiro, J. Mol. Catal. A: Chem., 2004, 224, 189; (c) J. Zhang, Y. Tang, G. Li and C. Hu, Appl. Catal., A, 2005, 278, 251; (d) M. Jian, L. Zhu, J. Wang, J. Zhang, G. Li and C. Hu, J. Mol. Catal. A: Chem., 2006, 253, 1; (e) Y. Zhu, Y. Dong, L. Zhao and F. Yuan, J. Mol. Catal. A: Chem., 2010, 315, 205; $(f)$ Q. Liu, L. Zhu, L. Li, B. Guo, X. Hu and C. Hu, J. Mol. Catal. A: Chem., 2010, 331, 71; $(g)$ P. K. Khatri, B. Singh, S. L. Jain, B. Sain and A. K. Sinha, Chem. Commun., 2011, 47, 1610.

28 (a) C. Ohde and C. Limberg, Chem. - Eur. J., 2010, 16, 6892; (b) N. Jiang and A. J. Ragauskas, J. Org. Chem., 2007, 72, 7030; (c) A. T. Radosevich, C. Musich and F. D. Toste, J. Am. Chem. Soc., 2005, 127, 1090; (d) V. D. Pawar, S. Bettigeri, S. S. Weng, J. Q. Kao and C. T. Chen, J. Am. Chem. Soc., 2006, 128, 6308.

29 (a) M. R. Maurya, A. A. Khan, A. Azam, S. Ranjan, N. Mondal, A. Kumar, F. Avecilla and J. C. Pessoa, Dalton Trans., 2010, 39, 1345; (b) M. R. Maurya, A. A. Khan, A. Azam, A. Kumar, S. Ranjan, N. Mondal and J. C. Pessoa, Eur. J. Inorg. Chem., 2009, 5377; (c) H. B. ten Brink, H. E. Schoemaker and R. Wever, Eur. J. Biochem., 2001, 268, 132; (d) C. Bolm and F. Bienewald, Angew. Chem., Int. Ed. Engl., 1995, 34, 2640; (e) G. Santoni, G. M. Licini and D. Rehder, Chem. - Eur. J., 2003, 9, 4700.

30 (a) P. Adão, J. C. Pessoa, R. T. Henriques, M. L. Kuznetsov, F. Avecilla, M. R. Maurya, U. Kumar and I. Correia, Inorg. Chem., 2009, 48, 3542; (b) S. M. de Lima, J. A. Gómez, V. P. Barros, G. de S. Vertuan, M. das Dores Assis, C. F. de Oliveira Graeff and G. J.-F. Demets, Polyhedron, 2010, 29, 3008; (c) V. Conte and B. Floris, Dalton Trans., 2011, 40, 1419.

31 (a) R. Dinda, P. Sengupta, M. Sutradhar, T. C. W. Mak and S. Ghosh, Inorg. Chem., 2008, 47, 5634; (b) S. P. Dash, S. Majumder, A. Banerjee, M. F. N. N. Carvalho, P. Adão, J. C. Pessoa, K. Brzezinski, E. Garribba, H. Reuter and R. Dinda, Inorg. Chem., 2016, 55, 1165.

32 (a) R. Dinda, P. Sengupta, S. Ghosh and T. C. W. Mak, Inorg. Chem., 2002, 41, 1684; (b) R. Dinda, P. K. Majhi, P. Sengupta, S. Pasayat and S. Ghosh, Polyhedron, 2010, 29, 248; (c) S. P. Dash, S. Pasayat, S. Bhakat, H. R. Dash, S. Das, R. J. Butcher and R. Dinda, Polyhedron, 2012, 31, 524; (d) S. P. Dash, S. Pasayat, S. Bhakat, S. Roy, R. Dinda, E. R. T. Tiekink, S. Mukhopadhyay, S. K. Bhutia, M. R. Hardikar, B. N. Joshi, Y. P. Patil and M. Nethaji, Inorg. Chem., 2013, 52, 14096; (e) S. P. Dash, A. K. Panda, S. Pasayat, R. Dinda, A. Biswas, E. R. T. Tiekink, Y. P. Patil, M. Nethaji, W. Kaminsky, S. Mukhopadhyay and S. K. Bhutia, Dalton Trans., 2014, 43, 10139.

33 S. Patra, S. Chatterjee, T. K. Si and K. K. Mukherjea, Dalton Trans., 2013, 42, 13425.
34 S. Pasayat, S. P. Dash, S. Roy, R. Dinda, S. Dhaka, M. R. Maurya, W. Kaminsky, Y. P. Patil and M. Nethaji, Polyhedron, 2014, 67, 1.

35 S. P. Dash, Nonoxido and Oxido Vanadium Complexes Featuring $\mathrm{O}$ - and $\mathrm{N}$-donor Ligands in Relation to Biological and Catalytic activities, Ph.D. thesis, National Institute of Technology, Rourkela, India, 2015.

36 E. Blanc, D. Schwarzenbach and H. D. Flack, J. Appl. Crystallogr., 1991, 24, 1035.

37 G. M. Sheldrick, Acta Crystallogr., Sect. A: Fundam. Crystallogr., 2008, 64, 112.

38 Saswati, A. Chakraborty, S. P. Dash, A. K. Panda, R. Dinda, A. Biswas, S. Mukhopadhyay, S. K. Bhutia, A. Crochet and R. Acharyya, Dalton Trans., 2015, 6140.

39 S. P. Dash, A. K. Panda, S. Pasayat, R. Dinda, A. Biswas, E. R. T. Tiekink, S. Mukhopadhyay, S. K. Bhutia, W. Kaminsky and E. Sinn, RSC Adv., 2015, 5, 51852.

40 S. P. Dash, A. K. Panda, S. Pasayat, S. Majumder, A. Biswas, W. Kaminsky, S. Mukhopadhyay, S. K. Bhutia and R. Dinda, J. Inorg. Biochem., 2015, 144, 1.

41 P. K. Sasmal, A. K. Patra and A. R. Chakravarty, J. Inorg. Biochem., 2008, 102, 1463.

42 D. C. Crans, M. L. Tarlton and C. C. McLauchlan, Eur. J. Inorg. Chem., 2014, 4450.

43 (a) H. Glas, E. HerdTweck, G. R. J. Artus and W. R. Thil, Inorg. Chem., 1998, 37, 3644; (b) Y. Soon, M. Melchior, D. A. Summers, R. C. Thompson, S. J. Retting and C. Orvig, Inorg. Chem., 1998, 37, 3119; (c) M. R. Maurya, S. Khurana, C. Schulzke and D. Rehder, Eur. J. Inorg. Chem., 2001, 779.

44 S. Das, G. P. Muthukumaragopal, S. N. Pal and S. Pal, New J. Chem., 2003, 27, 1102.

45 G. Lenglet and M. H. David-Cordonnier, J. Nucleic Acids, 2010, 2010.

46 N. Poklar, D. S. Pilch, S. J. Lippard, E. A. Redding, S. U. Dunham and K. J. Breslauer, Proc. Natl. Acad. Sci. U. S. A., 1996, 93, 7606.

47 L. Li, Q. Guo, J. Dong, T. Xu and J. Li, J. Photochem. Photobiol., B, 2013, 125, 56.

48 S. Saha, R. Majumdar, M. Roy, R. R. Dighe and A. R. Chakravarty, Inorg. Chem., 2009, 48, 2652.

49 P. Krishnamoorthy, P. Sathyadevi, A. H. Cowley, R. R. Butorac and N. Dharmaraj, Eur. J. Med. Chem., 2011, 46, 3376.

50 P. K. Sasmal, S. Saha, R. Majumdar, S. De, R. R. Dighe and A. R. Chakravarty, Dalton Trans., 2010, 39, 2147.

51 N. D. Chasteen, in Biological Magnetic Resonance, ed. J. Reuben, Plenum, New York, 1981, p. 53.

52 A. G. J. Ligtenbarg, R. Hage and B. L. Feringa, Coord. Chem. Rev., 2003, 237, 89.

53 G. J. Colpas, B. J. Hamstra, J. W. Kampf and V. L. Pecoraro, J. Am. Chem. Soc., 1996, 118, 3469.

54 Encyclopedia of Chemical Technology, ed. E. Clark, J. I. Keroschwitz and M. Howe-Grant, Wiley, New York, 1997, vol. 23, p. 134.

55 P. C. B. Page, Organosulfur Chemistry I and II, Springer, Berlin, 1999. 